Article

\title{
The Long-Term Effect of Petroleum-Derived Substances and Their Bioremediation on the Host Plant (Vicia faba L.) and a Herbivore (Sitona spp.)
}

\author{
Janina Gospodarek ${ }^{1, * \mathbb{D}}$, Milena Rusin ${ }^{1}$ and Aleksandra Nadgórska-Socha ${ }^{2}$ \\ 1 Department of Microbiology and Biomonitoring, University of Agriculture in Kraków, Al. Mickiewicza 21, \\ 31-120 Krakow, Poland; milena_rusin@wp.pl \\ 2 Department of Ecology, University of Silesia in Katowice, Bankowa 9, 40-007 Katowice, Poland; \\ aleksandra.nadgorska-socha@us.edu.pl \\ * Correspondence: rrjgospo@cyf-kr.edu.pl
}

Received: 19 June 2020; Accepted: 20 July 2020; Published: 23 July 2020

\begin{abstract}
The present study assessed distant-in-time effects of soil contamination with petroleum-derived substances (PDSs) (petrol, diesel fuel and used engine oil) and their bioremediation using ZB-01 biopreparation on the growth of broad bean, content of nutrients and heavy metals in plants, and feeding by imagines and larvae of Sitona spp. The results showed that even after 5 years from the moment of soil contamination by engine oil and diesel fuel, they negatively impacted the growth of broad bean plants. PDSs significantly modified the content of nutrients and generally increased the content of heavy metals in plant organs. These substances also negatively affected the feeding of adult Sitona spp., causing a reduction in the percentage of plants damaged by beetles, and a decrease in the surface of consumed areas on leaves. The ZB-01 biopreparation had a generally positive effect on the morphological features of plants, and its effect on the content of nutrients and heavy metals was variable, depending on the type of contaminant, the analyzed metals or nutrients, and the involved part of the plant. The biopreparation also inhibited the adverse effect of PDSs on the feeding by imago of Sitona spp.
\end{abstract}

Keywords: agricultural soil contamination; bacterial degradation; petroleum products; broad bean; phytophagous insects

\section{Introduction}

In recent years, petroleum and its derivatives have become one of the principal sources of contamination of soil and water worldwide [1,2]. Increasing industrialization and the development of motorization have generated an ever-increasing demand for petroleum products. The increase in the extraction, processing, and use of petroleum-derived substances (PDSs) leads to an enhanced risk of the contamination of the environment with these substances [3-5]. Aromatic hydrocarbons, a component of petroleum and PDSs, exert teratogenic, mutagenic, carcinogenic, cytotoxic, and immunotoxic effects on living organisms [6-9]. These effects are associated with the ability to accumulate these compounds in plants and with their transfer to the subsequent links of the trophic chain [10-12].

In the groundwater environment, the components of petroleum undergo microbial and chemical transformations depending on a number of processes, e.g., oxidation, evaporation, sedimentation, dispersion, emulsification, adsorption, and dissolving in groundwater and surface water [2]. These transformations are usually very slow, and therefore, new techniques are continuously developed for eliminating PDSs from the soil. In recent years, the importance of biological methods of decontamination has increased, because they offer high effectiveness while ensuring safety of the 
natural environment [13-15]. One of these methods is bioremediation, which consists of eliminating the contaminants from soil and groundwater by using living organisms, usually leading to the transformation of various types of contaminants into their less harmful forms. This method utilizes the natural capabilities of microorganisms to decompose the hydrocarbons of petroleum [16-18]. ZB-01 biopreparation is an example of a microbial preparation whose usefulness in the decomposition of petroleum-derived contaminants has been already confirmed $[19,20]$. It contains a mixture of selected prokaryotic organisms, mainly bacteria (Stenotrophomonas, Pseudomonas, Moraxella, Acinetobacter, Alcaligenes, Ochrobactrum, Comamonas, Burkholderia, Corynebacterium, and Oligella).

The effects of PDSs on the physical and chemical properties of soil, as well as on the morphological features and chemical composition of plants growing in contaminated soil, are relatively well known. Plant growth is weakened by PDSs [21-26], while changes in the contents of nutrients and other elements (e.g., heavy metals) depend on the plant species, PDSs, and type of analyzed component [27-29]. The available literature provides information on the effect of petroleum on the natural environment immediately after the emergence of a contamination or after a short time. However, scarce data are available on the subsequent (distant-in-time) effects of PDSs on the elements of the environment indirectly reacting to this factor, i.e., plants and herbivores. Changes occurring over time in soil due to the effect of PDSs, as well as the applied remediation, may affect plant growth differently (this may be observed as negative impact with variable intensity, no impact, or positive impact). Time is an additional factor (apart from the factors mentioned above) that can modify the chemical composition of plants. Changes in the appearance and nutritional value of host plants affect the appearance of herbivores and their feeding.

Because of their diversity, ease of collection and breeding, high fertility rate, and short period of development, arthropods, including Sitona beetles (Sitona spp.), are a useful tool for determining the effects of contamination on the subsequent links of the trophic chain. Adult Sitona beetles eat out circular holes on the borders of leaves, thereby significantly decreasing the assimilation area. The larvae feed on root nodules and reduce the amount of $\mathrm{N}$ fixation by plants as well as disturb water management, which consequently weakens the growth and development of plants. Furthermore, the broad bean (Vicia faba L.), which is one of the chief host plants for Sitona spp., is a particularly useful test plant, both as a bioindicator of soil contamination by PDSs [30] and as a detector of mutagenic substances [31,32]. In our studies, the system comprising soil, a plant (broad bean), and a herbivore (Sitona beetles) was used to trace the distant-in-time consequences of soil contamination with PDSs and the effects of bioremediation.

The present study aimed to determine the subsequent effects (after 5 years) of soil contamination with the selected PDSs such as petrol, diesel fuel, and used engine oil on the growth of broad bean plants, content of nutrients and heavy metals in plants, and feeding by imagines and larvae of Sitona beetles. The evaluation was extended to cover the effect of bioremediation enhanced by the application of ZB-01 biopreparation on all the above mentioned parameters.

\section{Materials and Methods}

\subsection{Experimental Setup}

The field experiment was set up in November 2009 in the premises of the Experimental Station of the University of Agriculture in Krakow, located in Mydlniki near Krakow (Poland; 50.0815 ${ }^{\circ} \mathrm{N}, 19.84730^{\circ}$ E). It consisted of four treatments in two series: one with microbiological bioremediation (R) and one without it (0R) (eight treatments in total). In each series, the following treatments were performed: (1) Control treatment- uncontaminated soil (C), (2) Soil artificially contaminated with petrol (P), (3) Soil artificially contaminated with diesel fuel (DF), and (4) Soil artificially contaminated with used engine oil (EO). Native soil (loamy sand; sand $750 \mathrm{~g} \mathrm{~kg}^{-1}$, silt $210 \mathrm{~g} \mathrm{~kg}^{-1}$, clay $40 \mathrm{~g} \mathrm{~kg}^{-1} ; \mathrm{pH}(\mathrm{KCl})=6.45$; $\mathrm{pH}\left(\mathrm{H}_{2} \mathrm{O}\right)=7.12 ;$ total carbon $=10.4 \mathrm{~g} \mathrm{~kg}^{-1} ; \mathrm{N}=0.90 \mathrm{~g} \mathrm{~kg}^{-1} ; \mathrm{C}: \mathrm{N}=11.6 ; \mathrm{CaCO}_{3}=1.7 \mathrm{~g} \mathrm{~kg}^{-1}$;

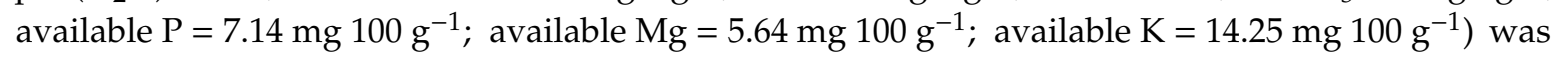


placed in specially adapted containers (certified for storing substances such as oils, petroleum products, and solvents) of $1 \mathrm{~m}^{3}$ capacity $(1 \mathrm{~m} / 1 \mathrm{~m} / 1 \mathrm{~m})$, while preserving the natural arrangement of soil layers. Works were performed manually to minimize the impact on the soil structure and indigenous fauna. Each layer was approximately $15 \mathrm{~cm}$ deep (7 layers in total). Next, the containers were sunk into the ground so that their edges were on the same level as the surrounding soil. Additionally, the upper sections of the container sides were perforated to allow free access of the contaminated soil to invertebrates, as the experiment aimed to assess the influence of PDSs and bioremediation on the soil-plant-herbivore relationship under conditions as close as possible to natural conditions. The containers were double-bottomed. The upper bottom, propped on supports, was perforated to enable the possible effluence of water (also containing contaminants). A tank was installed on the side of each container below its bottom (connected with the container bottom) to collect the possible effluent from the soil inside the container. The tank was provided with a plastic duct running toward the surface, which enabled excess water to be pumped out. This procedure was adopted in the experiment to avoid environmental pollution with effluents from the contaminated soil. All containers were also supplied with perforated plastic tubes (placed at approximately $30 \mathrm{~cm}$ distance, 4 per container) to provide adequate soil aeration by gravity, which is a prerequisite for bioremediation to proceed correctly. Next, after 8 months (including winter months), which allowed the soil to return to the density close to the natural one and regain its biological efficiency, the artificial contamination of soil in containers by the abovementioned PDSs was performed in June 2010. The 8-month period was set according to the common good agricultural practice and information about the influence of pre-winter soil tillage on its physical properties [33,34]. The doses, corresponding to $6000 \mathrm{mg} \mathrm{kg}^{-1}$ of dry mass (i.e., typical petroleum concentration in medium-contaminated soils), were applied by pouring the measured quantity of a given PDS on the soil surface in the container. Petrol and diesel fuel were obtained from a BP petrol station; the engine oil was obtained from an Orlen petrol station, and it was used for one year (in a petrol-combustion engine) prior to application in this experiment (BP and Orlen are the names of petrol companies). After 1 week and in series with bioremediation, then again one year after the moment of soil contamination, ZB-01 biopreparation was added by sprinkling it on the ground surface while maintaining $60 \%$ sorption humidity of the soil. The application was performed only twice because the role of ZB-01 was to initiate and support the process of natural remediation of the soil. The use of biopreparation was preceded by adding a compound fertilizer (Azofoska; $13.6 \% \mathrm{~N}, 2.8 \% \mathrm{P}$, and $15.8 \% \mathrm{~K}$ ) at the dose of $100 \mathrm{~g}$ per container. ZB-01 contained selected prokaryotic organisms, which were isolated over years from sites heavily polluted with organic compounds. It was specially prepared for this experiment in the Biochemistry Department of the University of Agriculture in Kraków. The experiment was conducted in four repetitions, selected according to the randomized block method. For the next 3 years, the soil was left undisturbed, allowing the natural succession of plants, and then in 2013, broad bean plants were cultivated followed by winter wheat.

After 1 month from soil contamination, the content of total petroleum hydrocarbons (TPH) in the soil was monitored. Compared to the TPH content in the control, soil contaminated with EO had more than 10 times higher TPH content, soil contaminated with DF had almost 4 times higher TPH content, and soil contaminated with P had similar TPH content to that of the control. Inoculation with ZB-01 biocenosis enabled the degradation of the petroleum derivatives present in the soil contaminated with DF and EO with $82.3 \%$ and $75.4 \%$ efficiency, respectively, after 24 months [19].

\subsection{Plants}

In the beginning of April 2015, the seeds of broad bean (of the "Bartek" variety) were sown in the soils in containers, with 30 seeds per container (in accordance with the sowing standard) after prior soil preparation (loosening and fertilizing). Pre-sowing fertilization with Polifoska fertilizer was applied, which supplied the soil with $2.88 \mathrm{~g} \mathrm{~N}, 8.64 \mathrm{~g} \mathrm{P}_{2} \mathrm{O}_{5}$, and $8.64 \mathrm{~g} \mathrm{~K}_{2} \mathrm{O}$ per container. The percentage of germinating seeds was high, approximately $90-100 \%$ (27-30 seedlings per container). After seedling 
emergence, the plants were thinned out to have exactly the same number of plants in each container, i.e., 25 .

\subsection{Plant Growth}

The plant morphology was assessed at the stage of processing maturity (milk-ripe) of broad bean seeds. Six plants were randomly collected from each container, and the following elements were then determined: total length of shoots; number of leaves, pods, and seeds; mass of the aboveground part; length and mass of roots in $0-30 \mathrm{~cm}$ soil layer, and number of produced nodules from the same soil layer. The remaining plants were left in containers until their full maturity, and they were used to assess the damage caused by the broad bean seed beetle Bruchus rufimanus Boh. (results not included in this paper).

\subsection{Analysis of Metal Concentration in Plants Samples}

To determine the concentrations of macroelements $(\mathrm{Ca}, \mathrm{Mg}, \mathrm{K}, \mathrm{P}, \mathrm{S})$ and trace elements (Fe, $\mathrm{Zn}$, $\mathrm{Ni}, \mathrm{Cu}, \mathrm{Mn}, \mathrm{Cd}, \mathrm{Pb}, \mathrm{Sr}, \mathrm{Ba}, \mathrm{As})$ in plant samples (6 randomly selected plants from each container), the plant material was cleaned of any patches of deposited aphid honeydew and other surface contaminants, washed in tap water, followed by washing in distilled water, and dried at $105^{\circ} \mathrm{C}$. Dried plant tissues were then ground in a stainless steel mill. Dry weight subsamples $0.25 \mathrm{~g}$ were wet digested in concentrated $\mathrm{HNO}_{3}$ at the maximum of $120{ }^{\circ} \mathrm{C}$ and then diluted to $25 \mathrm{~mL}$ with deionized water [35]. The contents of trace elements and macroelements were measured by inductively coupled plasma emission spectroscopy (Spectroblue ICP-OES Analyzer; Spectro Analytical Instruments, Kleve, Germany) [36]. The quality of the analytical procedure was checked using a reference material (Certified Reference Material CTA-OTL-1, Oriental Tobacco Leaves) with the same quantities of samples.

\subsection{Sitona spp. Feeding}

The estimates of feeding of imagines included a fourfold analysis, which began at the time of the first symptoms of damage noted on emerging plants and continued once a week. Sitona beetles were naturally present (not introduced on purpose), because we wanted to assess the influence of changes in plant appearance and their chemical composition on preferences of Sitona while choosing host plants and on intensity of feeding in conditions closest to natural ones. The feeding intensity of beetles were estimated by measuring the loss of leaf surface (by comparing the surface area of consumed places in leaves, expressed in $\mathrm{mm}^{2}$, to the total area of leaves) and the area of consumed places, and by counting damaged and undamaged leaves. The estimates of the areas of leaf damage caused by beetles were calculated using plotting paper to determine leaf surfaces and the sizes of the consumed areas on 10 randomly selected and marked plants in each of the containers. Damaged and undamaged leaves were counted on all plants in the containers. The feeding of larvae was determined by the analyses of underground parts of plants. For this purpose, the roots were removed from the soil (0-30 cm layer), and after a thorough washing, the exact total number of root nodules and the number of damaged nodules were counted. The analysis was performed once at the end of June and in the beginning of July along with the collection of plants to estimate morphological parameters.

\subsection{Statistical Analysis}

The obtained results were analyzed and checked for normality (Shapiro-Wilk test with Lilliefors correction) and equality of variance (Levene's test). The tests showed that transformation of the data was not required. The significance of differences between the means was tested by two-factor (one factor was pollution: EO, DF, $\mathrm{P}$, and $\mathrm{C}$ and the second factor was use of biopreparation: $\mathrm{OR}$ and R) variance analysis (STATISTICA 12.5 software). The mean values were differentiated by Fisher's LSD (least significant difference) test at $p<0.05$. The variables were as follows: the morphological characteristics of $V$. faba plants; the content of macronutrients and trace elements in the aboveground parts and roots of $V$. faba plants; the ratio of selected nutrients; and the feeding intensity of adult 
and larvae of Sitona beetles. Principal Component Analysis (PCA; STATISTICA 12.5 software) was used to assess the relationships between Sitona feeding and PDS contamination as well as between element content in $V$. faba organs and PDS contamination. Multiple regression equations were derived to determine which of the accumulated heavy metal and nutrient content influenced Sitona feeding.

\section{Results}

Five years after soil contamination (i.e., in the year when this experiment was carried out), the content of $\mathrm{C}_{6}-\mathrm{C}_{12}$ hydrocarbons (in accordance with the standard PN-ISO 22155: 2013) in all contaminated soils was lower than $0.8 \mathrm{mg} \mathrm{kg}^{-1}$, however, the content of $\mathrm{C}_{12}-\mathrm{C}_{36}$ hydrocarbons (in accordance with the standard PN-EN ISO 16703: 2011) in the soils contaminated with EO and DF was still higher than that in the control soil $\left(600 \mathrm{mg} \mathrm{kg}^{-1}\right.$ in EO, $370 \mathrm{mg} \mathrm{kg}^{-1}$ in DF, $9.5 \mathrm{mg} \mathrm{kg}^{-1}$ in $\mathrm{P}$ and $<6 \mathrm{mg} \mathrm{kg}^{-1}$ in control). The content of $\mathrm{C}_{12}-\mathrm{C}_{36}$ hydrocarbons in the treatments subjected to bioremediation at that time was $520 \mathrm{mg} \mathrm{kg}^{-1}$ in EO, $190 \mathrm{mg} \mathrm{kg}^{-1}$ in DF, and $<6 \mathrm{mg} \mathrm{kg}^{-1}$ in $\mathrm{P}$.

\subsection{Plant Growth}

Five years after soil contamination by PDSs, the broad bean plants growing in the soil contaminated with DF had a lower mass of aboveground parts and a lower number of developed pods and root nodules than the control plants (Tables 1 and 2). Moreover, EO caused nearly a fourfold decrease in the number of developed root nodules, but similar to that observed for $\mathrm{P}$, it did not affect the remaining analyzed morphological features of plants.

Table 1. The effect of petroleum-derived substances and bioremediation on morphological characteristics of Vicia faba L. The values are expressed per plant.

\begin{tabular}{ccccc}
\hline Treatment & Total Length of Shoots (cm) & Number of Leaves (pcs.) & Number of Pods (pcs.) & Number of Seeds (pcs.) \\
\hline EO 0R & $132.20( \pm 78.8)^{\mathrm{b}}$ & $107.42( \pm 43.1)^{\mathrm{ab}}$ & $2.20( \pm 0.3)^{\mathrm{ab}}$ & $4.90( \pm 0.1)^{\mathrm{a}}$ \\
EO R & $146.08( \pm 4.4)^{\mathrm{bc}}$ & $113.00( \pm 1.3)^{\mathrm{ab}}$ & $2.83( \pm 0.2)^{\mathrm{b}}$ & $4.67( \pm 0.3)^{\mathrm{a}}$ \\
DF 0R & $94.67( \pm 19.1)^{\mathrm{a}}$ & $77.83( \pm 4.5)^{\mathrm{a}}$ & $1.08( \pm 0.2)^{\mathrm{a}}$ & $2.33( \pm 0.2)^{\mathrm{a}}$ \\
DF R & $157.17( \pm 9.9)^{\mathrm{bcd}}$ & $120.08( \pm 8.9)^{\mathrm{ab}}$ & $2.50( \pm 0.7)^{\mathrm{ab}}$ & $5.75( \pm 2.6)^{\mathrm{a}}$ \\
P 0R & $138.91( \pm 49.4)^{\mathrm{b}}$ & $119.08( \pm 39.9)^{\mathrm{ab}}$ & $2.50( \pm 1.6)^{\mathrm{ab}}$ & $6.08( \pm 3.6)^{\mathrm{a}}$ \\
P R & $176.75( \pm 21.0)^{\mathrm{cd}}$ & $148.50( \pm 25.1)^{\mathrm{b}}$ & $2.25( \pm 0.3)^{\mathrm{ab}}$ & $6.58( \pm 0.5)^{\mathrm{a}}$ \\
C 0R & $123.22( \pm 13.1)^{\mathrm{ab}}$ & $110.92( \pm 22.5)^{\mathrm{ab}}$ & $3.00( \pm 1.5)^{\mathrm{b}}$ & $6.67( \pm 2.8)^{\mathrm{a}}$ \\
C R & $181.75( \pm 51.4)^{\mathrm{d}}$ & $156.83( \pm 19.8)^{\mathrm{b}}$ & $3.08( \pm 0.8)^{\mathrm{b}}$ & $6.83( \pm 0.2)^{\mathrm{a}}$ \\
\hline
\end{tabular}

EO—soil contaminated with engine oil, DF—soil contaminated with diesel fuel, $\mathrm{P}$-soil contaminated with petrol, C - control soil, $0 \mathrm{R}$-without biopreparation, $\mathrm{R}$-with biopreparation. Means $( \pm \mathrm{SE}$-standard error) within columns marked with the same letters do not differ significantly according to the LSD (least significant difference) test at $p<0.05$.

Table 2. The effect of petroleum-derived substances and bioremediation on morphological characteristics of Vicia faba L. The values are expressed per plant. Continued.

\begin{tabular}{ccccc}
\hline Treatment & Mass of Aboveground Part (g) & Length of Root (cm) & Mass of Root (g) & Number of Developed Root Nodules (pcs.) \\
\hline EO OR & $139.82( \pm 4.7)^{\mathrm{b}}$ & $11.60( \pm 3.1)^{\mathrm{a}}$ & $21.14( \pm 5.3)^{\mathrm{a}}$ & $18.50( \pm 7.9)^{\mathrm{a}}$ \\
EO R & $151.58( \pm 9.9)^{\mathrm{b}}$ & $13.92( \pm 1.4)^{\mathrm{a}}$ & $20.94( \pm 1.9)^{\mathrm{a}}$ & $32.75( \pm 11.4)^{\mathrm{ab}}$ \\
DF 0R & $84.36( \pm 6.7)^{\mathrm{a}}$ & $13.83( \pm 2.9)^{\mathrm{a}}$ & $20.17( \pm 6.0)^{\mathrm{a}}$ & $24.83( \pm 2.2)^{\mathrm{a}}$ \\
DF R & $172.72( \pm 28.0)^{\mathrm{c}}$ & $13.92( \pm 0.7)^{\mathrm{a}}$ & $25.85( \pm 5.6)^{\mathrm{a}}$ & $36.00( \pm 3.3)^{\mathrm{ab}}$ \\
P OR & $159.48( \pm 41.4)^{\mathrm{bc}}$ & $12.67( \pm 2.8)^{\mathrm{a}}$ & $21.86( \pm 4.3)^{\mathrm{a}}$ & $62.67( \pm 11.9)^{\mathrm{bc}}$ \\
P R & $185.68( \pm 33.1)^{\mathrm{cd}}$ & $12.83( \pm 4.1)^{\mathrm{a}}$ & $24.18( \pm 5.7)^{\mathrm{a}}$ & $55.00( \pm 18.9)^{\mathrm{b}}$ \\
C OR & $159.09( \pm 16.8)^{\mathrm{bc}}$ & $13.89( \pm 2.9)^{\mathrm{a}}$ & $23.25( \pm 3.0)^{\mathrm{a}}$ & $67.83( \pm 2.1)^{\mathrm{c}}$ \\
C R & $217.57( \pm 10.7)^{\mathrm{d}}$ & $13.33( \pm 3.1)^{\mathrm{a}}$ & $25.32( \pm 9.1)^{\mathrm{a}}$ & $63.92( \pm 11.7)^{\mathrm{c}}$ \\
\hline
\end{tabular}

Means $( \pm \mathrm{SE})$ within columns marked with the same letters do not differ significantly according to the LSD test at $p<0.05$. Symbols as in Table 1.

In the control soil and in DF-contaminated soil, the application of ZB-01 biopreparation significantly increased the total length of shoots per plant and increased the mass of the aboveground parts of plants. Furthermore, in P-contaminated soil, the biopreparation increased the length of shoots by more than $37 \mathrm{~cm}$ compared to that in the soil not treated with the biopreparation. There was no significant impact of the applied bioremediation on the morphological features of plants growing in the EO-contaminated soil. 


\subsection{Plant Components and Heavy Metal Content}

All the PDSs used in the experiment significantly decreased the $\mathrm{Ca}$ and $\mathrm{Mg}$ content of the aboveground parts of broad bean plants. However, a reverse relationship was found in the roots of the analyzed plants. The contamination of the soil with $\mathrm{EO}$ and DF resulted in a significant increase in the content of $\mathrm{K}$ (by $1.68 \mathrm{~g} \mathrm{~kg}^{-1}$ for EO, and by $6.84 \mathrm{~g} \mathrm{~kg}^{-1}$ for DF) and $\mathrm{P}$ (by $2.44 \mathrm{~g} \mathrm{~kg}^{-1}$ for EO, and by $1.18 \mathrm{~g} \mathrm{~kg}^{-1}$ for DF) in the aboveground parts, and there was also an increase in $\mathrm{S}$ content in the roots of plants (Tables 3 and 4). In general, P (petrol) did not affect the content of the analyzed nutrients, and it only decreased the $\mathrm{S}$ content in the aboveground parts of plants by $2.09 \mathrm{~g} \mathrm{~kg}^{-1}$ compared to that in the control treatment.

Table 3. The effect of petroleum-derived substances and bioremediation on the content of selected nutrients in the aboveground parts (AP) and roots of Vicia faba L. $\left(\mathrm{g} \mathrm{kg}^{-1}\right)$.

\begin{tabular}{|c|c|c|c|c|c|c|}
\hline \multirow{2}{*}{ Treatment } & \multicolumn{2}{|c|}{$\mathbf{S}$} & \multicolumn{2}{|c|}{$\mathbf{P}$} & \multicolumn{2}{|c|}{$\mathbf{K}$} \\
\hline & AP & Roots & AP & Roots & AP & Roots \\
\hline EO OR & $5.74( \pm 0.2)^{c}$ & $8.27( \pm 0.3)^{e}$ & $11.78( \pm 0.3)^{\mathrm{e}}$ & $6.92( \pm 0.9)^{\mathrm{c}}$ & $14.43( \pm 0.4)^{b}$ & $15.54( \pm 0.6)^{c}$ \\
\hline DF OR & $5.49( \pm 0.7)^{c}$ & $4.37( \pm 0.4)^{b c}$ & $10.52( \pm 0.6)^{d}$ & $5.21( \pm 0.5)^{\mathrm{ab}}$ & $19.59( \pm 0.7)^{d}$ & $12.61( \pm 0.6)^{b}$ \\
\hline DF R & $5.17( \pm 0.3)^{c}$ & $5.87( \pm 0.3)^{d}$ & $7.09( \pm 0.4)^{\mathrm{a}}$ & $4.45( \pm 0.4)^{\mathrm{a}}$ & $18.90( \pm 0.7)^{\mathrm{d}}$ & $14.87( \pm 0.3)^{\mathrm{c}}$ \\
\hline P OR & $3.55( \pm 0.4)^{a}$ & $3.95( \pm 0.0)^{a b}$ & $8.50( \pm 0.4)^{b c}$ & $6.15( \pm 0.6)^{b c}$ & $16.26( \pm 0.8)^{c}$ & $11.81( \pm 0.8)^{a b}$ \\
\hline C OR & $5.64( \pm 0.3)^{c}$ & $3.73( \pm 0.3)^{\mathrm{a}}$ & $9.34( \pm 0.6)^{c}$ & $6.83( \pm 0.8)^{c}$ & $12.75( \pm 0.4)^{\mathrm{a}}$ & $11.84( \pm 0.7)^{a b}$ \\
\hline C R & $5.17( \pm 0.1)^{\mathrm{c}}$ & $4.10( \pm 0.1)^{\mathrm{ab}}$ & $11.32( \pm 1.1) \mathrm{de}$ & $7.01( \pm 0.6)^{c}$ & $15.99( \pm 0.8)^{c}$ & $10.92( \pm 0.9)^{\mathrm{a}}$ \\
\hline
\end{tabular}

Means $( \pm \mathrm{SE})$ within columns marked with the same letters do not differ significantly according to the LSD test at $p<0.05$. Symbols as in Table 1 .

Table 4. The effect of petroleum-derived substances and bioremediation on the content of selected nutrients in the aboveground parts (AP) and roots of Vicia faba L. $\left(\mathrm{g} \mathrm{kg}^{-1}\right)$. Continued.

\begin{tabular}{ccccc}
\hline \multirow{2}{*}{ Treatment } & \multicolumn{2}{c}{ Ca } & \multicolumn{2}{c}{ Mg } \\
\cline { 2 - 5 } & AP & Roots & AP & Roots \\
\hline EO 0R & $7.02( \pm 0.5)^{\mathrm{b}}$ & $5.16( \pm 0.5)^{\mathrm{c}}$ & $2.03( \pm 0.1)^{\mathrm{b}}$ & $1.12( \pm 0.1)^{\mathrm{f}}$ \\
EO R & $9.07( \pm 0.2)^{\mathrm{d}}$ & $2.36( \pm 0.2)^{\mathrm{a}}$ & $2.03( \pm 0.1)^{\mathrm{b}}$ & $0.82( \pm 0.1)^{\mathrm{cd}}$ \\
DF 0R & $6.03( \pm 0.4)^{\mathrm{a}}$ & $4.12( \pm 0.2)^{\mathrm{b}}$ & $1.86( \pm 0.1)^{\mathrm{a}}$ & $0.88( \pm 0.1)^{\mathrm{d}}$ \\
DF R & $8.12( \pm 0.4)^{\mathrm{c}}$ & $2.48( \pm 0.4)^{\mathrm{a}}$ & $1.85( \pm 0.1)^{\mathrm{a}}$ & $0.87( \pm 0.1)^{\mathrm{d}}$ \\
P 0R & $8.93( \pm 0.4)^{\mathrm{d}}$ & $4.37( \pm 0.3)^{\mathrm{b}}$ & $2.02( \pm 0.1)^{\mathrm{b}}$ & $0.75( \pm 0.0)^{\mathrm{bc}}$ \\
P R & $9.44( \pm 0.4)^{\mathrm{de}}$ & $3.64( \pm 0.7)^{\mathrm{b}}$ & $1.75( \pm 0.1)^{\mathrm{a}}$ & $0.70( \pm 0.0)^{\mathrm{b}}$ \\
C 0R & $10.03( \pm 0.1)^{\mathrm{e}}$ & $2.50( \pm 0.1)^{\mathrm{a}}$ & $2.18( \pm 0.0)^{\mathrm{c}}$ & $0.61( \pm 0.1)^{\mathrm{a}}$ \\
C R & $7.98( \pm 0.6)^{\mathrm{c}}$ & $4.26( \pm 0.6)^{\mathrm{b}}$ & $2.07( \pm 0.1)^{\mathrm{bc}}$ & $1.01( \pm 0.1)^{\mathrm{e}}$ \\
\hline
\end{tabular}

Means $( \pm$ SE) within columns marked with the same letters do not differ significantly according to the LSD test at $p<0.05$. Symbols as in Table 1.

The ZB-01 biopreparation applied to the EO-contaminated soil decreased the content of all analyzed nutrients in the roots of plants. It also decreased the content of $\mathrm{S}$ and $\mathrm{P}$, but increased $\mathrm{Ca}$ content in the aboveground parts of broad bean plants. For the DF-contaminated soil, the biopreparation increased the content of $\mathrm{Ca}$ in the aboveground parts as well as increasing $\mathrm{S}$ and $\mathrm{K}$ content in the roots of plants. It, however, caused a decrease in P content (by $3.43 \mathrm{~g} \mathrm{~kg}^{-1}$ ) in the aboveground parts and in Ca content (by $1.64 \mathrm{~g} \mathrm{~kg}^{-1}$ ) in the roots of broad bean plants. After the application of the biopreparation, the plants growing in the P-contaminated soil showed lower content of $\mathrm{K}$ and $\mathrm{Mg}$ in the aboveground parts. The biopreparation applied to the control soil increased the content of $\mathrm{P}$ and $\mathrm{K}$ in the aboveground parts and of $\mathrm{Ca}$ in the roots of plants, but there was also a decrease in Ca content in the aboveground parts.

All the PDSs used in the experiments significantly decreased the value of the $\mathrm{Ca} / \mathrm{Mg}$ index in the aboveground parts of plants and also decreased the value of the $\mathrm{K} /(\mathrm{Ca}+\mathrm{Mg})$ index in their roots (Figure $1 \mathrm{a}, \mathrm{b})$. In the DF-contaminated soil, the value of the $\mathrm{K} /(\mathrm{Ca}+\mathrm{Mg})$ index was significantly higher 
(by 1.44) for the aboveground parts than in the control treatment; similarly, in the P-contaminated soil, the value of the $\mathrm{Ca} / \mathrm{Mg}$ index for roots was higher by 1.73 than that in the control. The biopreparation applied to the contaminated soils generally reduced the differences in the values of the analyzed indices when compared with the control (increase in the $\mathrm{Ca} / \mathrm{Mg}$ index in the aboveground parts and decrease in the $\mathrm{K} /(\mathrm{Ca}+\mathrm{Mg})$ index in roots). Furthermore, it decreased the value of the $\mathrm{Ca} / \mathrm{Mg}$ index in the roots in all contaminated soils. In the control treatment, the biopreparation decreased the value of the $\mathrm{Ca} / \mathrm{Mg}$ index by 0.74 in the aboveground parts and decreased the value of the $\mathrm{K} /(\mathrm{Ca}+\mathrm{Mg})$ index by 1.74 in the roots.

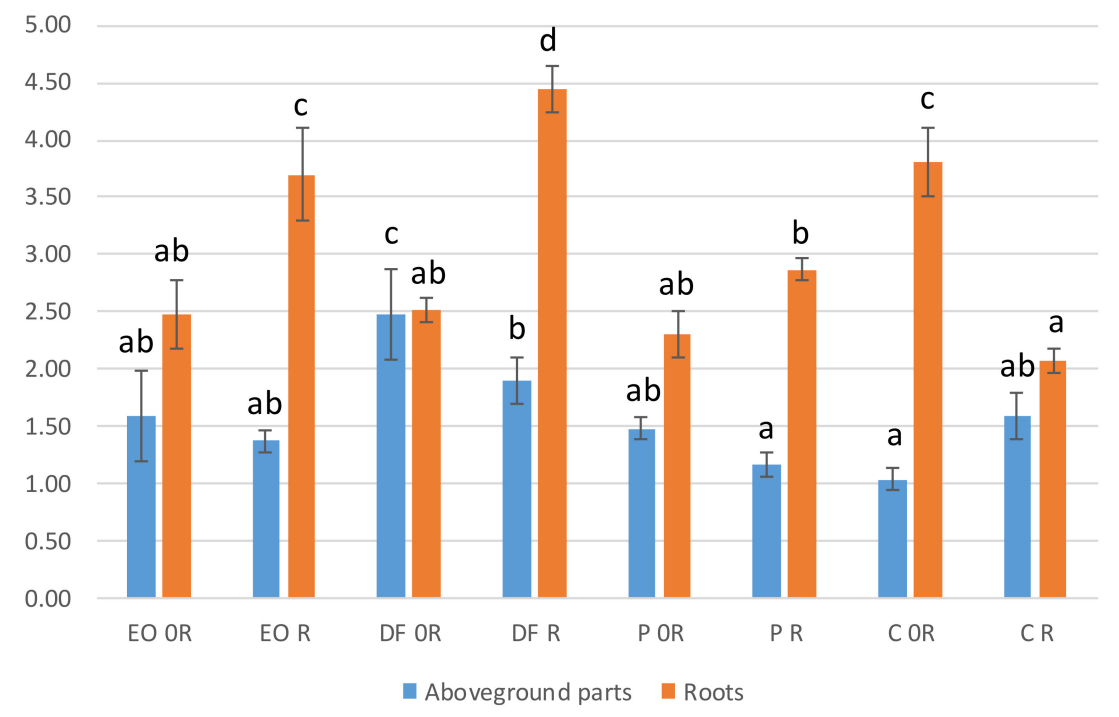

(a)

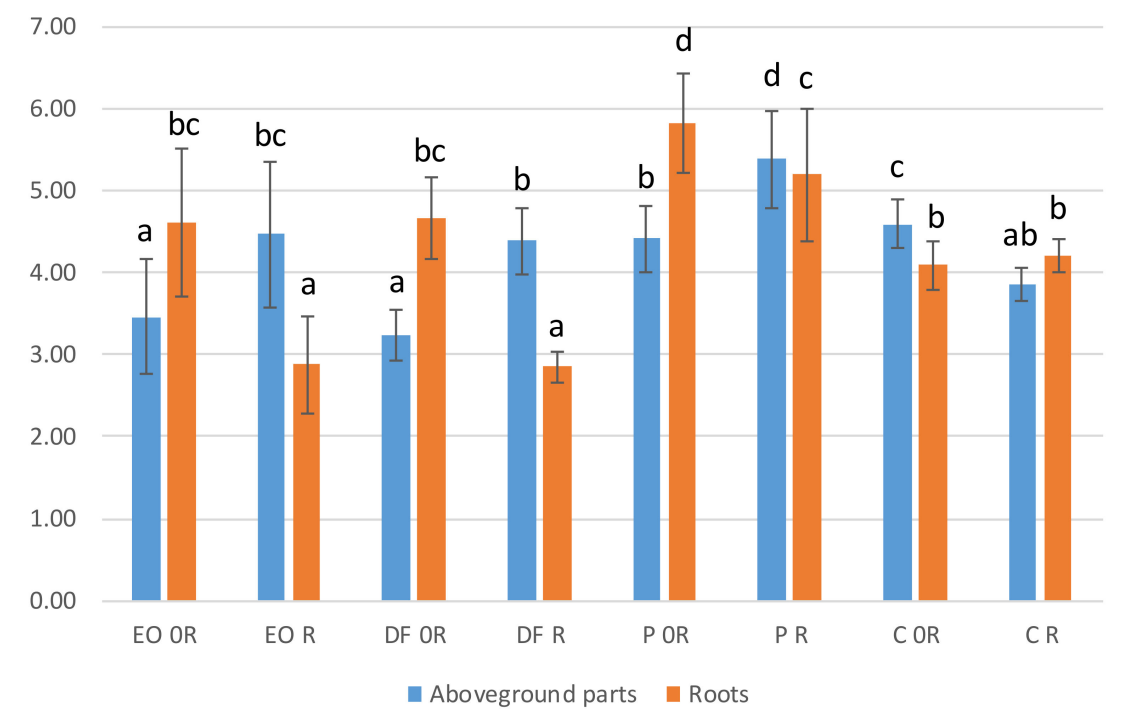

(b)

Figure 1. The effect of petroleum-derived substances and bioremediation on the ratio of nutrients in Vicia faba L. (a) $\mathrm{K} /(\mathrm{Ca}+\mathrm{Mg})$; (b) $\mathrm{Ca} / \mathrm{Mg}$. Symbols as in Table 1. Means $( \pm \mathrm{SE})$ marked with the same letters (separately for the aboveground parts and roots) do not differ significantly according to the LSD test at $p<0.05$. 
All the PDSs used in the experiment significantly increased the content of $\mathrm{Cd}, \mathrm{Pb}$, and $\mathrm{Zn}$ in the roots of broad bean plants. Furthermore, in the roots of plants growing in the soils contaminated with $\mathrm{EO}$ and DF, a nearly twofold increase in Cu content was noted when compared with that in the control plants. The contamination with $\mathrm{P}$ decreased the content of $\mathrm{Pb}$ (by $2.39 \mathrm{mg} \mathrm{kg}^{-1}$ ), $\mathrm{Zn}$ (by $17.51 \mathrm{mg} \mathrm{kg}^{-1}$ ), and $\mathrm{Cu}$ (by $3.61 \mathrm{mg} \mathrm{kg}^{-1}$ ) in the aboveground parts of plants. The EO contamination significantly increased the content of $\mathrm{Zn}$ and $\mathrm{Cu}$ in the aboveground parts and the content of $\mathrm{Ni}$ in the roots, while in the aboveground parts of plants, DF contamination increased $\mathrm{Pb}$ content but decreased $\mathrm{Zn}$ content (Tables 5 and 6).

Table 5. The effect of petroleum-derived substances and bioremediation on the content of cadmium, lead and zinc in the aboveground parts (AP) and roots of Vicia faba L. $\left(\mathrm{mg} \mathrm{kg}^{-1}\right)$.

\begin{tabular}{ccccccc}
\hline \multirow{2}{*}{ Treatment } & \multicolumn{2}{c}{ Cd } & \multicolumn{2}{c}{ Pb } & \multicolumn{2}{c}{ Zn } \\
\cline { 2 - 7 } & AP & Roots & AP & Roots & AP & Roots \\
\hline EO 0R & $0.57( \pm 0.1)^{\mathrm{ab}}$ & $1.49( \pm 0.2)^{\mathrm{d}}$ & $4.20( \pm 1.3)^{\mathrm{b}}$ & $6.95( \pm 1.1)^{\mathrm{b}}$ & $140.18( \pm 2.4)^{\mathrm{d}}$ & $155.59( \pm 9.1)^{\mathrm{d}}$ \\
EO R & $0.84( \pm 0.1)^{\mathrm{c}}$ & $1.00( \pm 0.3)^{\mathrm{c}}$ & $4.90( \pm 1.0)^{\mathrm{b}}$ & $13.62( \pm 1.5)^{\mathrm{c}}$ & $109.08( \pm 3.2)^{\mathrm{b}}$ & $112.27( \pm 12.9)^{\mathrm{c}}$ \\
DF 0R & $0.44( \pm 0.1)^{\mathrm{ab}}$ & $1.01( \pm 0.2)^{\mathrm{c}}$ & $9.50( \pm 0.9)^{\mathrm{c}}$ & $24.27( \pm 3.8)^{\mathrm{d}}$ & $107.64( \pm 3.9)^{\mathrm{b}}$ & $73.87( \pm 7.1)^{\mathrm{b}}$ \\
DF R & $0.57( \pm 0.1)^{\mathrm{ab}}$ & $1.33( \pm 0.1)^{\mathrm{cd}}$ & $3.88( \pm 0.8)^{\mathrm{b}}$ & $8.43( \pm 1.0)^{\mathrm{b}}$ & $137.23( \pm 9.2)^{\mathrm{d}}$ & $106.00( \pm 6.5)^{\mathrm{c}}$ \\
P 0 R & $0.40( \pm 0.2)^{\mathrm{ab}}$ & $0.36( \pm 0.0)^{\mathrm{b}}$ & $1.49( \pm 0.2)^{\mathrm{a}}$ & $8.01( \pm 1.7)^{\mathrm{b}}$ & $106.15( \pm 8.5)^{\mathrm{b}}$ & $79.09( \pm 10.1)^{\mathrm{b}}$ \\
P R & $0.38( \pm 0.2)^{\mathrm{ab}}$ & $0.42( \pm 0.3)^{\mathrm{b}}$ & $2.05( \pm 0.5)^{\mathrm{a}}$ & $9.03( \pm 1.1)^{\mathrm{b}}$ & $75.62( \pm 6.4)^{\mathrm{a}}$ & $73.45( \pm 11.6)^{\mathrm{b}}$ \\
C 0R & $0.35( \pm 0.2)^{\mathrm{a}}$ & $0.21( \pm 0.1)^{\mathrm{a}}$ & $3.88( \pm 0.1)^{\mathrm{b}}$ & $3.22( \pm 0.1)^{\mathrm{a}}$ & $123.66( \pm 3.6)^{\mathrm{c}}$ & $30.97( \pm 1.1)^{\mathrm{a}}$ \\
C R & $0.61( \pm 0.1)^{\mathrm{bc}}$ & $0.54( \pm 0.3)^{\mathrm{b}}$ & $4.09( \pm 1.3)^{\mathrm{b}}$ & $7.67( \pm 0.2)^{\mathrm{b}}$ & $163.65( \pm 7.6)^{\mathrm{e}}$ & $77.89( \pm 6.7)^{\mathrm{b}}$ \\
\hline
\end{tabular}

Means ( \pm SE) within columns marked with the same letters do not differ significantly according to the LSD test at $p<0.05$. Symbols as in Table 1.

Table 6. The effect of petroleum-derived substances and bioremediation on the content of nickel and copper in the aboveground parts (AP) and roots of Vicia faba L. $\left(\mathrm{mg} \mathrm{kg}^{-1}\right)$.

\begin{tabular}{ccccc}
\hline \multirow{2}{*}{ Treatment } & \multicolumn{2}{c}{ Ni } & \multicolumn{2}{c}{ Cu } \\
\cline { 2 - 5 } & AP & Roots & AP & Roots \\
\hline EO 0R & $1.70( \pm 0.4)^{\mathrm{ab}}$ & $5.94( \pm 1.2)^{\mathrm{c}}$ & $14.92( \pm 1.8)^{\mathrm{e}}$ & $20.75( \pm 2.1)^{\mathrm{d}}$ \\
EO R & $1.64( \pm 0.2)^{\mathrm{ab}}$ & $4.23( \pm 0.8)^{\mathrm{b}}$ & $12.91( \pm 0.3)^{\mathrm{cd}}$ & $14.84( \pm 1.4)^{\mathrm{b}}$ \\
DF 0R & $1.98( \pm 0.1)^{\mathrm{bc}}$ & $3.50( \pm 0.5)^{\mathrm{ab}}$ & $12.31( \pm 1.0)^{\mathrm{bc}}$ & $16.43( \pm 1.2)^{\mathrm{bc}}$ \\
DF R & $1.69( \pm 0.1)^{\mathrm{ab}}$ & $4.18( \pm 0.7)^{\mathrm{b}}$ & $10.51( \pm 0.7)^{\mathrm{ab}}$ & $16.43( \pm 2.3)^{\mathrm{bc}}$ \\
P 0R & $1.45( \pm 0.1)^{\mathrm{a}}$ & $3.58( \pm 0.6)^{\mathrm{ab}}$ & $8.77( \pm 1.7)^{\mathrm{a}}$ & $11.43( \pm 0.5)^{\mathrm{a}}$ \\
P R & $1.66( \pm 0.3)^{\mathrm{ab}}$ & $3.44( \pm 0.3)^{\mathrm{ab}}$ & $10.71( \pm 0.4)^{\mathrm{b}}$ & $17.44( \pm 1.3)^{\mathrm{bc}}$ \\
C 0R & $1.72( \pm 0.1)^{\mathrm{ab}}$ & $2.50( \pm 0.3)^{\mathrm{a}}$ & $12.38( \pm 1.1)^{\mathrm{bcd}}$ & $8.85( \pm 0.8)^{\mathrm{a}}$ \\
C R & $2.31( \pm 0.6)^{\mathrm{c}}$ & $3.32( \pm 0.6)^{\mathrm{ab}}$ & $14.28( \pm 1.0)^{\mathrm{de}}$ & $17.50( \pm 3.2)^{\mathrm{bc}}$ \\
\hline
\end{tabular}

Means ( \pm SE) within columns marked with the same letters do not differ significantly according to the LSD test at $p<0.05$. Symbols as in Table 1.

In the majority of cases, the application of the biopreparation to the EO-contaminated soil decreased the content of the analyzed heavy metals in the aboveground parts ( $\mathrm{Zn}$ and $\mathrm{Cu}$ ) and roots $(\mathrm{Cd}, \mathrm{Zn}, \mathrm{Ni}$, and $\mathrm{Cu})$ of the broad bean plants, while a reverse relationship was noted in the control treatment (increase in the content of $\mathrm{Cd}, \mathrm{Zn}$, and $\mathrm{Ni}$ in the aboveground parts and increase in the content of $\mathrm{Cd}, \mathrm{Pb}, \mathrm{Zn}$, and $\mathrm{Cu}$ in the roots of plants). In the DF-contaminated soil, the biopreparation significantly increased the content of $\mathrm{Zn}$ (by approximately $30 \mathrm{mg} \mathrm{kg}^{-1}$ ) in the aboveground parts and roots of plants, but it also led to a nearly threefold decrease in the content of $\mathrm{Pb}$ in the analyzed organs of plants. In the P-contaminated soil, the biopreparation increased $\mathrm{Cu}$ content in the aboveground parts and roots, but decreased $\mathrm{Zn}$ content in the aboveground parts of plants.

On the one hand, all the PDSs used in the experiment increased the content of $\mathrm{Fe}, \mathrm{Mn}, \mathrm{Sr}, \mathrm{Ba}$, As, and $\mathrm{Al}$ in the roots of broad bean plants (Tables 7 and 8). On the other hand, they decreased $\mathrm{Fe}$ and Mn content in the aboveground parts. The plants growing in the EO- and DF-contaminated soil demonstrated that the $\mathrm{Sr}$ content in the aboveground parts was lower by $10.48 \mathrm{mg} \mathrm{kg}^{-1}$ and $8.72 \mathrm{mg} \mathrm{kg}^{-1}$, respectively, but the $\mathrm{Al}$ content was higher by 140.35 and $94.70 \mathrm{mg} \mathrm{kg}^{-1}$, respectively. 
The presence of DF in the soil also led to a more than fourfold increase in the Ba content of the aboveground parts. The P-contaminated soil increased the Sr content of the aboveground parts of plants by $3.93 \mathrm{mg} \mathrm{kg}^{-1}$ compared to that of the control plants.

Table 7. The effect of petroleum-derived substances and bioremediation on the content of iron, manganese and strontium in the aboveground parts (AP) and roots of Vicia faba L. $\left(\mathrm{mg} \mathrm{kg}^{-1}\right)$.

\begin{tabular}{ccccccc}
\hline \multirow{2}{*}{ Treat-Ment } & \multicolumn{2}{c}{ Fe } & \multicolumn{2}{c}{ Mn } & \multicolumn{2}{c}{ Sr } \\
\cline { 2 - 7 } & AP & Roots & AP & Roots & AP & Roots \\
\hline EO 0R & $302.36( \pm 18.7)^{\mathrm{e}}$ & $1432.08( \pm 121.4)^{\mathrm{c}}$ & $43.03( \pm 1.1)^{\mathrm{b}}$ & $97.65( \pm 5.4)^{\mathrm{c}}$ & $28.84( \pm 2.4)^{\mathrm{a}}$ & $35.62( \pm 2.3)^{\mathrm{d}}$ \\
EO R & $254.57( \pm 17.2)^{\mathrm{d}}$ & $1106.68( \pm 81.0)^{\mathrm{b}}$ & $38.44( \pm 1.0)^{\mathrm{ab}}$ & $60.86( \pm 8.7)^{\mathrm{b}}$ & $37.27( \pm 0.6)^{\mathrm{bc}}$ & $18.20( \pm 0.6)^{\mathrm{a}}$ \\
DF 0R & $211.07( \pm 14.1)^{\mathrm{bc}}$ & $1593.40( \pm 87.7)^{\mathrm{cd}}$ & $54.62( \pm 1.8)^{\mathrm{c}}$ & $64.57( \pm 9.2)^{\mathrm{b}}$ & $30.60( \pm 2.1)^{\mathrm{a}}$ & $30.38( \pm 5.6)^{\mathrm{cd}}$ \\
DF R & $234.18( \pm 24.9)^{\mathrm{e}}$ & $1230.61( \pm 5.8)^{\mathrm{b}}$ & $51.97( \pm 6.8)^{\mathrm{c}}$ & $88.89( \pm 5.7)^{\mathrm{c}}$ & $40.32( \pm 1.9)^{\mathrm{cde}}$ & $20.45( \pm 3.4)^{\mathrm{ab}}$ \\
P 0R & $160.49( \pm 25.4)^{\mathrm{a}}$ & $1687.47( \pm 9.0)^{\mathrm{d}}$ & $43.28( \pm 6.4)^{\mathrm{b}}$ & $55.27( \pm 2.0)^{\mathrm{b}}$ & $43.25( \pm 2.3)^{\mathrm{e}}$ & $25.08( \pm 4.8)^{\mathrm{bc}}$ \\
P R & $152.83( \pm 18.6)^{\mathrm{a}}$ & $1428.58( \pm 152.3)^{\mathrm{c}}$ & $34.48( \pm 3.0)^{\mathrm{a}}$ & $58.25( \pm 5.9)^{\mathrm{b}}$ & $36.22( \pm 0.6)^{\mathrm{b}}$ & $25.67( \pm 4.2)^{\mathrm{bc}}$ \\
C 0R & $388.82( \pm 28.1)^{\mathrm{f}}$ & $609.63( \pm 36.8)^{\mathrm{a}}$ & $84.07( \pm 8.7)^{\mathrm{e}}$ & $29.01( \pm 5.2)^{\mathrm{a}}$ & $39.32( \pm 1.0)^{\mathrm{bcd}}$ & $16.67( \pm 1.4)^{\mathrm{a}}$ \\
C R & $182.42( \pm 11.3)^{\mathrm{ab}}$ & $1502.84( \pm 158.3)^{\mathrm{c}}$ & $69.18( \pm 2.6)^{\mathrm{d}}$ & $97.66( \pm 5.9)^{\mathrm{c}}$ & $41.30( \pm 2.8)^{\mathrm{de}}$ & $30.88( \pm 3.1)^{\mathrm{cd}}$ \\
\hline
\end{tabular}

Means $( \pm$ SE) within columns marked with the same letters do not differ significantly according to the LSD test at $p<0.05$. Symbols as in Table 1 .

Table 8. The effect of petroleum-derived substances and bioremediation on the content of barium, arsenic and aluminium in the aboveground parts (AP) and roots of Vicia faba L. $\left(\mathrm{mg} \mathrm{kg}^{-1}\right)$.

\begin{tabular}{ccccccc}
\hline \multirow{2}{*}{ Treat-Ment } & \multicolumn{2}{c}{ Ba } & \multicolumn{2}{c}{ As } & Al \\
\cline { 2 - 7 } & AP & Roots & AP & Roots & AP & Roots \\
\hline EO 0R & $15.32( \pm 13.0)^{\mathrm{ab}}$ & $32.50( \pm 5.3)^{\mathrm{d}}$ & $0.57( \pm 0.2)^{\mathrm{a}}$ & $2.04( \pm 0.2)^{\mathrm{e}}$ & $238.05( \pm 10.7)^{\mathrm{d}}$ & $1883.95( \pm 293.4)^{\mathrm{cd}}$ \\
EO R & $7.58( \pm 0.9)^{\mathrm{a}}$ & $17.29( \pm 1.6)^{\mathrm{b}}$ & $0.48( \pm 0.0)^{\mathrm{a}}$ & $1.12( \pm 0.1)^{\mathrm{ab}}$ & $161.84( \pm 10.2)^{\mathrm{c}}$ & $1742.06( \pm 247.4)^{\mathrm{bc}}$ \\
DF 0R & $45.80( \pm 6.5)^{\mathrm{d}}$ & $22.28( \pm 4.1)^{\mathrm{c}}$ & $0.67( \pm 0.2)^{\mathrm{a}}$ & $1.43( \pm 0.1)^{\mathrm{bcd}}$ & $187.40( \pm 48.8)^{\mathrm{c}}$ & $1421.62( \pm 192.4)^{\mathrm{b}}$ \\
DF R & $22.28( \pm 10.3)^{\mathrm{bc}}$ & $17.31( \pm 1.4)^{\mathrm{bc}}$ & $0.54( \pm 0.1)^{\mathrm{a}}$ & $1.38( \pm 0.3)^{\mathrm{bc}}$ & $190.55( \pm 47.7)^{\mathrm{c}}$ & $1904.88( \pm 80.2)^{\mathrm{cd}}$ \\
P 0R & $10.75( \pm 0.4)^{\mathrm{a}}$ & $14.57( \pm 0.5)^{\mathrm{b}}$ & $0.48( \pm 0.0)^{\mathrm{a}}$ & $1.54( \pm 0.2)^{\mathrm{bcde}}$ & $133.26( \pm 12.9)^{\mathrm{ab}}$ & $1516.19( \pm 24.5)^{\mathrm{b}}$ \\
P R & $45.80( \pm 2.5)^{\mathrm{d}}$ & $30.61( \pm 1.2)^{\mathrm{d}}$ & $0.70( \pm 0.3)^{\mathrm{a}}$ & $1.87( \pm 0.2)^{\mathrm{cde}}$ & $127.83( \pm 12.2)^{\mathrm{ab}}$ & $1711.26( \pm 269.9)^{\mathrm{bc}}$ \\
C 0R & $11.34( \pm 1.6)^{\mathrm{ab}}$ & $8.97( \pm 1.8)^{\mathrm{a}}$ & $0.50( \pm 0.1)^{\mathrm{a}}$ & $0.72( \pm 0.1)^{\mathrm{a}}$ & $92.70( \pm 0.9)^{\mathrm{a}}$ & $778.77( \pm 72.7)^{\mathrm{a}}$ \\
C R & $14.55( \pm 4.6)^{\mathrm{ab}}$ & $34.23( \pm 3.6)^{\mathrm{d}}$ & $0.55( \pm 0.0)^{\mathrm{a}}$ & $1.95( \pm 0.7)^{\mathrm{de}}$ & $131.83( \pm 7.4)^{\mathrm{ab}}$ & $2119.12( \pm 174.1)^{\mathrm{d}}$ \\
\hline
\end{tabular}

Means $( \pm$ SE) within columns marked with the same letters do not differ significantly according to the LSD test at $p<0.05$. Symbols as in Table 1 .

The ZB-01 biopreparation applied to the EO-contaminated soil decreased the content of the analyzed elements in plant roots. In the aboveground parts of plants, it decreased Fe content (by $47.79 \mathrm{mg} \mathrm{kg}^{-1}$ ) and $\mathrm{Al}$ content (by $76.21 \mathrm{mg} \mathrm{kg}^{-1}$ ), but increased Sr content (by $8.43 \mathrm{mg} \mathrm{kg}^{-1}$ ). After the application of the biopreparation, the broad bean plants growing in the DF-contaminated soil showed higher content of Fe and $\mathrm{Sr}$ in the aboveground parts and higher content of $\mathrm{Mn}$ and $\mathrm{Al}$ in roots; however, they showed lower content of $\mathrm{Ba}$ in their aboveground parts and lower content of Fe and $\mathrm{Sr}$ in their roots. In the P-contaminated soil, the biopreparation caused a more than fourfold increase in the Ba content in the aboveground parts and a more than twofold increase in the Ba content in roots; however, it also decreased the content of Mn and $\mathrm{Sr}$ in the aboveground parts and of Fe in the roots of plants. In the control treatment, the biopreparation increased the content of the analyzed metals in the roots of plants, but decreased Fe content (by $206.40 \mathrm{mg} \mathrm{kg}^{-1}$ ) and Mn content (by $14.89 \mathrm{mg} \mathrm{kg}^{-1}$ ) in their aboveground parts.

\subsection{Sitona spp. Feeding}

Five years after soil contamination, all PDSs used in the experiment significantly decreased the percentage of broad bean leaves damaged by Sitona beetles (Figure 2). The strongest impact was found for EO, where the percentage of leaves damaged by beetles was $18.34 \%$ lower than that in the control treatment. In the soils contaminated with EO and DF, the ZB-01 biopreparation significantly increased the analyzed feature by $12.48 \%$ and $5.63 \%$ for EO and DF, respectively. No impact of the applied bioremediation process on the percentage of leaves damaged by Sitona beetles was found in the P-contaminated soil and the control treatment. 


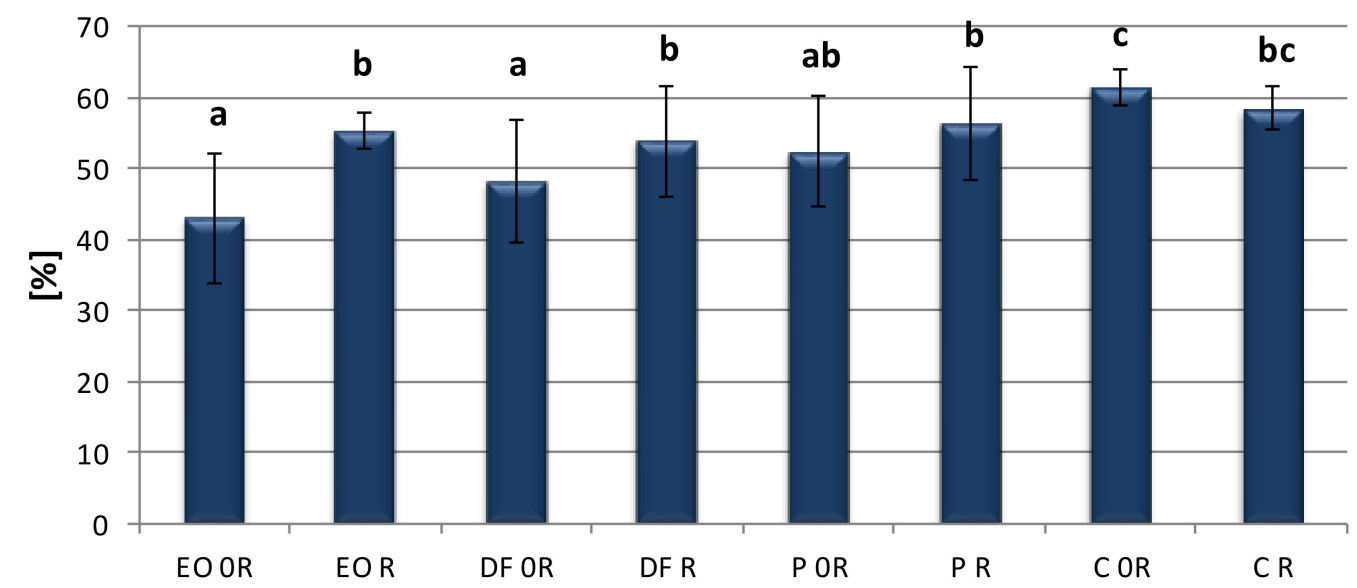

Figure 2. The effect of petroleum-derived substances and bioremediation on the percentage of leaves damaged by Sitona spp. (\%). Symbols as in Table 1. Means $( \pm \mathrm{SE})$ marked with the same letters do not differ significantly according to the LSD test at $p<0.05$.

All the PDSs used also significantly reduced the areas of leaves consumed by the analyzed insects (Figure 3). In the EO treatment, the surface of consumed areas per plant was smaller by $288.79 \mathrm{~mm}^{2}$ than that in the control treatment. In the DF and P treatments, it was reduced by $252.34 \mathrm{~mm}^{2}$, and $193.33 \mathrm{~mm}^{2}$, respectively. In all contaminated soils, the ZB-01 biopreparation led to nearly a twofold increase in the surfaces of areas consumed by beetles, but it had no significant effect on the value of the analyzed feature in the control treatment.

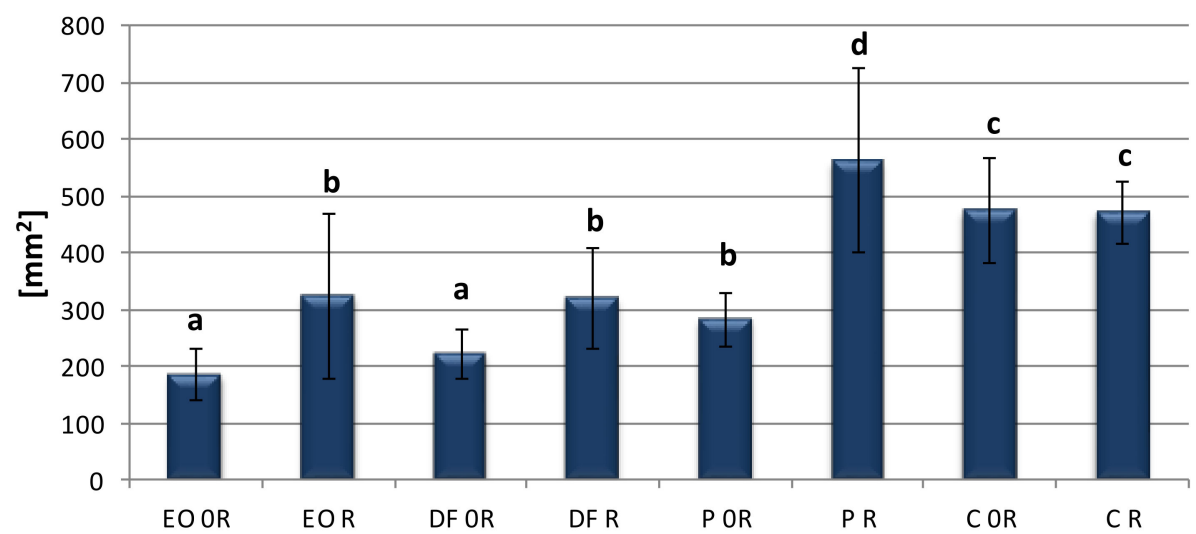

Figure 3. The effect of petroleum-derived substances and bioremediation on the surface of the area of consumed places in leaves per plant caused by Sitona spp. $\left(\mathrm{mm}^{2}\right)$. Symbols as in Table 1. Means $( \pm \mathrm{SE})$ marked with the same letters do not differ significantly according to the LSD test at $p<0.05$.

Only in the EO-contaminated soil was there a significantly smaller reduction in leaf blade resulting from the feeding by Sitona beetles when compared with the control treatment (by 0.29\%) (Figure 4). The remaining PDSs did not significantly affect the analyzed parameter. In all contamination treatments, the ZB-01 biopreparation significantly increased the lost surface of leaf blade; however, it did not affect the analyzed feature in the control treatment.

No significant effects of any of the applied PDSs and biopreparation were noted on the number of root nodules damaged by the larvae of Sitona beetles (Figure 5). The values were within the range of $15.21-20.52 \%$. 


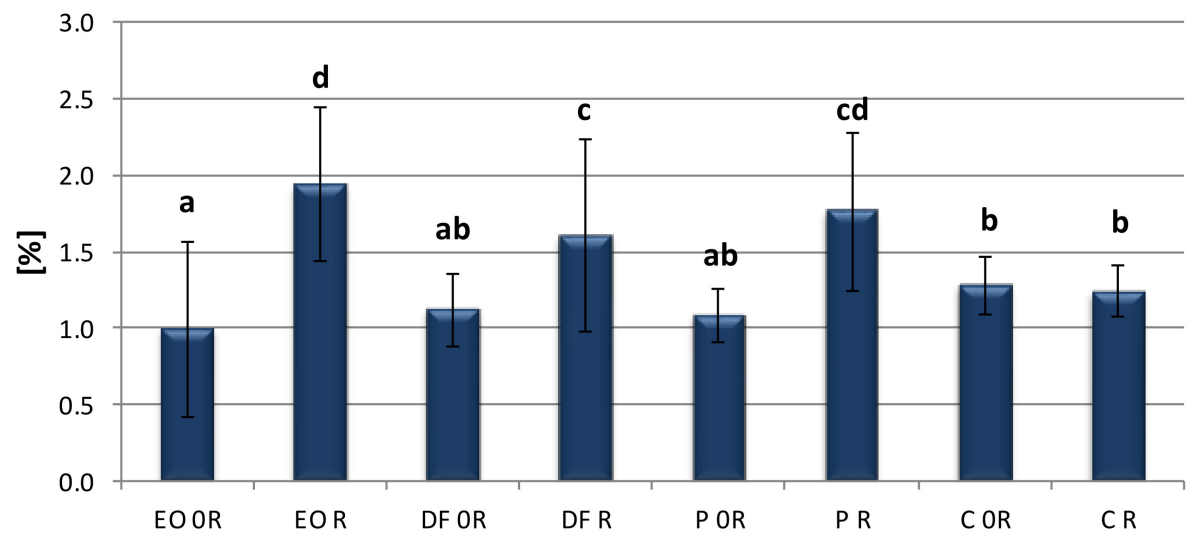

Figure 4. The effect of petroleum-derived substances and bioremediation on the loss of leaf surface caused by Sitona spp. (\%). Symbols as in Table 1. Means $( \pm \mathrm{SE})$ marked with the same letters do not differ significantly according to the LSD test at $p<0.05$.

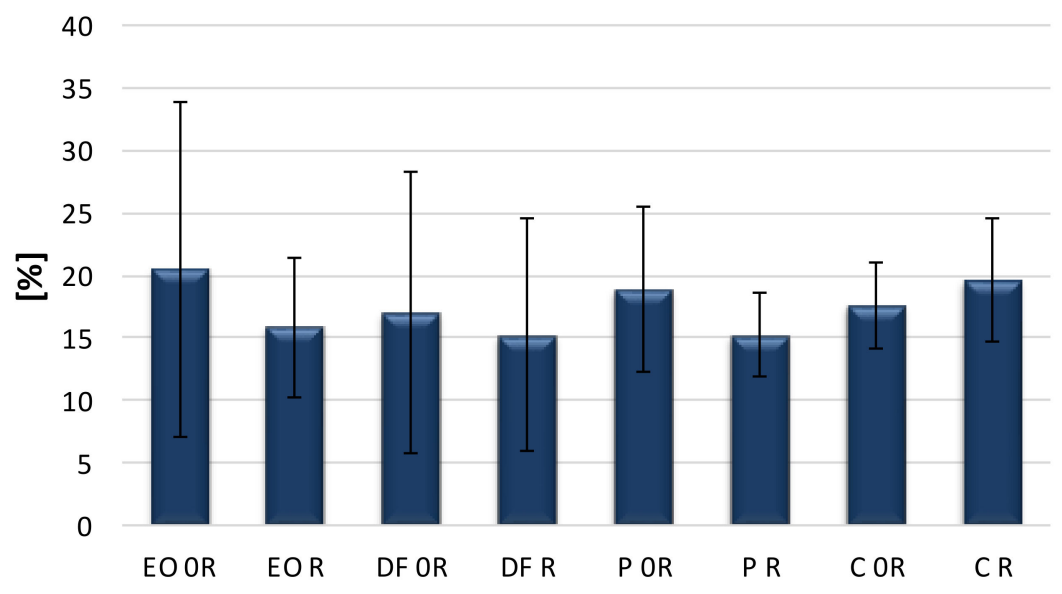

Figure 5. The effect of petroleum-derived substances and bioremediation on the number of root nodules damaged by the larvae of Sitona spp. (\%). Symbols as in Table 1. There were no statistically significant differences between treatments. Vertical bars denote \pm SE.

\subsection{Relationships between Sitona Feeding, Soil Contamination with PDSs and Broad Bean} Chemical Composition

The PCA of Sitona feeding and soil contamination with PDSs showed that the 1st and 2nd ordination axes explained together $39.51 \%$ of variation (Figure 7 ). The percentage of damaged leaves and leaf surface loss was positively correlated with both ordination axes, whereas the number of nodules and damaged nodules was correlated negatively with the 2 nd axis. The percentage of damaged nodules was also negatively correlated with the 1st ordination axis. The PCA analysis confirmed the negative influence of PDSs (DF and EO) on imago feeding and the production of root nodules by plants.

The PCA of the content of macroelements and trace elements in the organs of broad bean plants and soil contamination with PDSs allowed the differentiation of three principal components, among which the first two explained $30.51 \%$ of the variability in the analyzed samples (Figure 6). With the 1st axis, the content of $\mathrm{Fe}, \mathrm{Al}$, and $\mathrm{As}$ was the most negatively correlated, while the macroelements $\mathrm{Ca}$, $\mathrm{P}$, and $\mathrm{Mg}$ were the most positively correlated components. Next, the negative correlation with the 2nd ordination axis was noted for $\mathrm{S}$ and $\mathrm{Zn}$. 


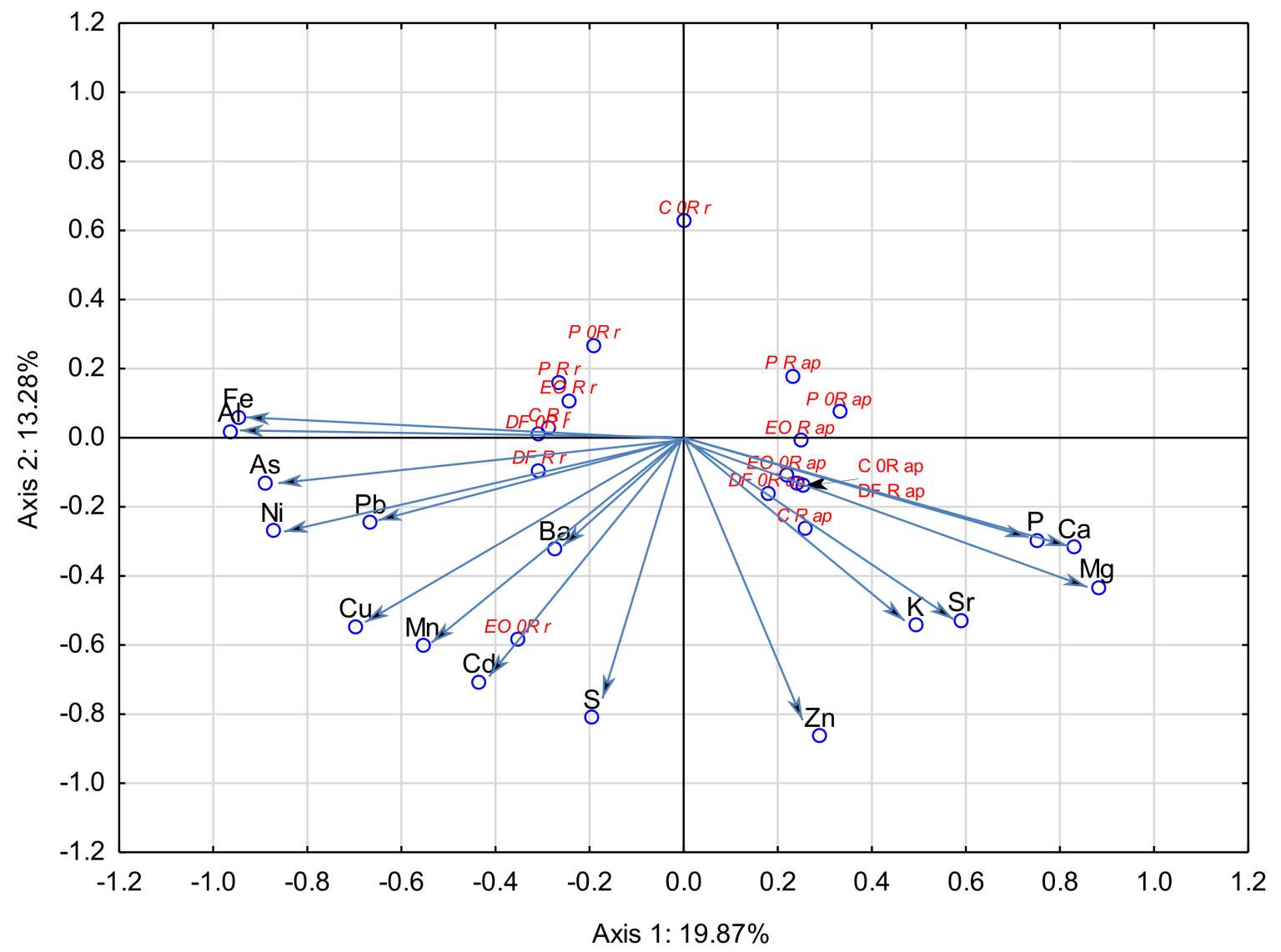

Figure 6. Principal component analysis of of element levels in V. faba organs, and soil contamination with petroleum-derived substances. Symbols as in Table 1, ap-aboveground parts, $\mathrm{r}$-roots.

Multiple regressions revealed that $\mathrm{Ca}$ and $\mathrm{Mn}$ had positive effects on imago feeding while Fe exerted a negative effect (Table 9). The percentage of damaged nodules was negatively affected by $\mathrm{Fe}, \mathrm{Mn}$, and $\mathrm{K}$ and positively by $\mathrm{Mg}$, $\mathrm{Ba}$, and $\mathrm{P}$. The negative effect of $\mathrm{Cd}, \mathrm{S}$, and $\mathrm{Pb}$ was noted on the number of root nodules developed in $V$. faba plants.

Table 9. Multiple regression equations $(p<0.05)$.

\begin{tabular}{cc}
\hline Trait & $\mathbf{R}^{\mathbf{2}}$ \\
\hline Damaged leaves $=39.28+1.34(\mathrm{Ca})-0.61(\mathrm{Fe})+0.59(\mathrm{Mn})$ & 0.90 \\
Eaten leaf area $=630.24+1.16(\mathrm{Ca})-0.68(\mathrm{Fe})+0.51(\mathrm{Mn})$ & 0.95 \\
Leaf blade loss $=0.65+1.81(\mathrm{Ca})$ & 0.86 \\
Number of nodules $=82.58+0.61(\mathrm{Mn})-0.48(\mathrm{Cd})-0.39(\mathrm{~S})-0.50(\mathrm{~Pb})$ & 0.97 \\
Damaged nodules $=10.44+0.63(\mathrm{Mg})-0.60(\mathrm{Fe})-0.31(\mathrm{Mn})-0.22(\mathrm{~K})+0.46(\mathrm{Ba})+0.31(\mathrm{P})$ & 0.95 \\
\hline
\end{tabular}




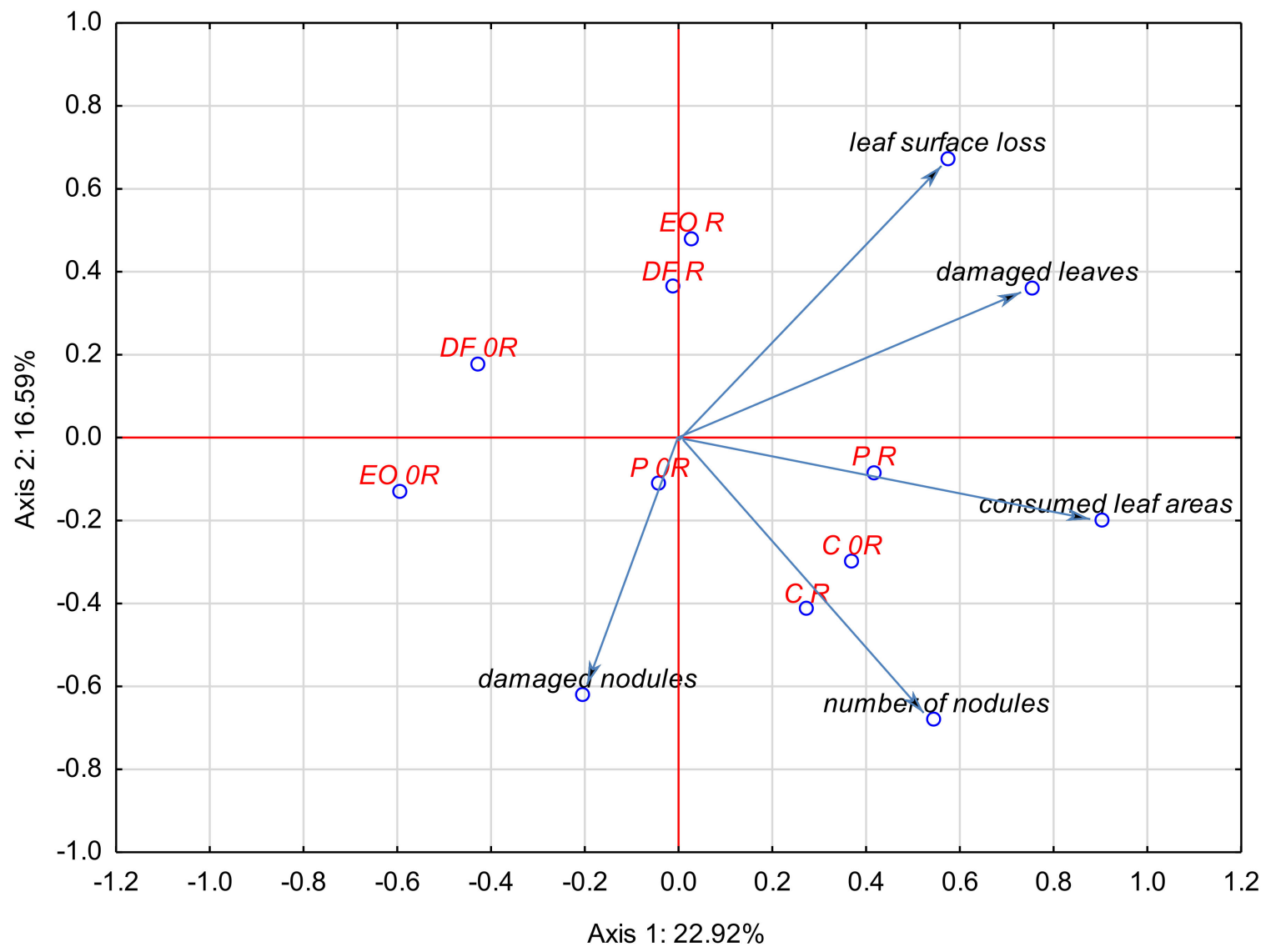

Figure 7. Principal component analysis of Sitona feeding, and soil contamination with PDSs. Symbols as in Table 1.

\section{Discussion}

The adverse impact of petroleum and PDSs on plants growing in contaminated soil has been confirmed by several authors [21-26]. Studies pertaining to this issue, however, were conducted a short time after the emergence of contamination. To date, there has been scarce information available on the long-term effects of this type of contaminant. In our earlier studies [27], which were conducted 3 years after soil contamination with PDSs, it was determined that DF adversely affected the growth of broad bean plants and reduced the number and mass of leaves (by $40 \%$ and $27 \%$, respectively), the number of pods (by 36\%), and the mass of shoots (by 32\%). Furthermore, the plants growing in the DF-contaminated soil had shorter roots and lower total length of shoots per plant (by $5.2 \mathrm{~cm}$ and $91.8 \mathrm{~cm}$, respectively). The EO-contaminated soil also caused adverse effects, but it was somewhat weaker than that of DF-contaminated soil. In the present experiment conducted 5 years after the contamination, the adverse effects of EO and DF on the growth of broad bean plants are still evident (DF reduced the mass of the aboveground parts by $47 \%$ and the number of developed pods and root nodules by approximately $64 \%$, while EO reduced the number of developed root nodules by as much as $73 \%$ ). On the one hand, this finding indicates the persistence of PDSs in the environment, and on the other hand, it indicates the sensitivity of broad bean to this type of pollution. The long-lasting impact of EO and DF on plants is probably associated with their chemical composition. Both EO and DF contain several hydrocarbons that stay in the soil environment for a long time and adversely affect the processes of transpiration and respiration in plants as well as the transportation of nutrients through cell membranes $[37,38]$. No significant subsequent effect of $P$ on the studied morphological features was found. This stems from the fact that $P$ contains significant quantities of volatile compounds that evaporate rapidly from the soil and from its higher susceptibility to natural biodegradation [39]. 
Studies pertaining to the long-term effect of the bioremediation process on cultivated plants are also very rare. Rusin et al. [27] demonstrated that after 3 years of soil contamination and the application of biopreparation to DF-contaminated soil, there was a positive effect on the growth of broad bean plants, with a significant increase in the number and mass of pods by approximately $70 \%$ and the number of seeds by $55 \%$. In the present experiment, the bioremediation process using the ZB- 01 biopreparation had a generally positive effect on the morphological features of broad bean plants. When applied to the DF-contaminated soil, it resulted in a nearly twofold increase in the total length of shoots and increased the mass of the aboveground parts of plants by nearly $50 \%$.

In an analogous experiment [27] conducted 2 years earlier, it was found that EO decreased the $\mathrm{S}$ content in the leaves of broad bean plants (by approximately $0.3 \mathrm{~g} \mathrm{~kg}^{-1}$ ), but no similar results were found for the remaining PDSs. In the present experiment, only P decreased the S content in the aboveground parts of broad bean plants by more than $2 \mathrm{~g} \mathrm{~kg}^{-1}$. However, DF and EO increased the content of this macrocomponent in the roots of plants. Our earlier study [30] revealed that the contamination of soil with EO and DF at the dose of $9 \mathrm{~g} \mathrm{~kg}^{-1}$ for each of these substances decreased the Ca content in the leaves of broad bean plants by $12 \%$ and $35 \%$, respectively. In the present experiment, the decrease in the content of this macrocomponent in the aboveground parts of plants in the presence of these two substances in the soil occurred at comparable levels (12\% for EO and $25 \%$ for DF). In the previous experiment, the nutrient content was analyzed 2 months after soil contamination; however, in the present experiment, it was performed after 5 years. This fact indicates the very long-lasting effects of these contaminants on plant composition. Moreover, in an earlier experiment [25], an increase in the Ca content in the roots of broad bean plants was found, which resulted from the presence of PDSs in the soil; this finding agrees with the results of the present experiment. Borowik and Wyszkowska [40] also found an almost threefold increase in the content of $\mathrm{Ca}$ in roots of maize grown in soil containing $\mathrm{DF}$ at the dose of $10 \mathrm{~cm}^{3} \mathrm{~kg}^{-1}$ of soil. However, other authors $[29,41]$ showed discrepancies regarding the influence of PDSs on Ca concentrations in plants, which was dependent on the plant species and the type and dose of the contaminant. Gospodarek and Nadgórska-Socha [28] demonstrated that the contamination of soil with $\mathrm{P}$ and $\mathrm{EO}$ at the dose of $3 \mathrm{~g} \mathrm{~kg}^{-1}$ decreased the $\mathrm{Mg}$ content in the leaves of broad bean plants by approximately $0.36 \mathrm{~g} \mathrm{~kg}^{-1}$. In our present experiment, all the applied PDSs decreased the content of this nutrient, while for DF, this decrease was maintained on a similar level $\left(0.32 \mathrm{~g} \mathrm{~kg}^{-1}\right)$ in the aboveground parts, although in the experiment mentioned above, the analyses were conducted immediately after the end of the vegetation season ( 3 months after soil contamination). Generally, in our experiment, PDSs increased the content of $\mathrm{K}$ (by $4 \mathrm{~g} \mathrm{~kg}^{-1}$, on average) and $\mathrm{P}$ (by $0.93 \mathrm{~g} \mathrm{~kg}^{-1}$, on average) in the aboveground parts of plants. No similar relationships were noted in our earlier studies [25], where the PDSs generally did not affect the content of $K$ in the leaves of broad bean plants, and moreover decreased the content of this macroelement in shoots. However, Wyszkowski and Ziółkowska [29] confirmed that DF and P at the dose of $2.5 \mathrm{~cm}^{3} \mathrm{~kg}^{-1}$ increased the content of phosphorus in spring rape by $1.51 \mathrm{~g} \mathrm{~kg}^{-1}$ and $0.13 \mathrm{~g} \mathrm{~kg}^{-1}$, respectively.

The available references provide only scarce information on the effect of enhanced bioremediation on the nutrient content of plants growing in soil contaminated with PDSs. Rusin et al. [27] demonstrated that bioremediation can reduce the differences between the content of some nutrient components in broad bean plants growing in contaminated soil and control soil. This partly corresponds with the results of the present study, particularly for the $\mathrm{Ca}$ and $\mathrm{P}$ content in the aboveground parts of plants. Similar results were also obtained by Borowik and Wyszkowska [40]. The authors stated that soil contamination with DF decreased the bioconcentration index of $\mathrm{P}, \mathrm{Ca}$ and $\mathrm{K}$ in maize. Remediation agents such as molecular sieve, alginite, sepiolite, and the Ikasorb 1850 sorbent minimized the adverse changes induced by this pollutant.

The value of $\mathrm{K} /(\mathrm{Ca}+\mathrm{Mg})$ index should remain within the limit of 1.6/1-2.1/1 for the optimum growth and development of plants [42]. In the present experiment, the $\mathrm{K} /(\mathrm{Ca}+\mathrm{Mg})$ index in the aboveground parts of plants was generally slightly lower than the optimum, but a marked increase in its value was noted in the roots of broad bean plants. The exceeding of the optimum value could 
stem from the fact that the demand for cations, reflecting the need to maintain proper ionic balance, increases in plants, and the $\mathrm{K}$ ion is taken up much faster than the Ca or Mg ions [42]. Rusin et al. [25] showed that DF significantly decreased the value of the $\mathrm{K} /(\mathrm{Ca}+\mathrm{Mg})$ index in the leaves, shoots, and roots of broad beans, but EO may increase it in the shoots of plants. In the present experiment, PDSs decreased the value of the $\mathrm{K} /(\mathrm{Ca}+\mathrm{Mg})$ index in the roots of plants but did not affect its value in the aboveground parts.

In the present experiment, the value of the $\mathrm{Ca} / \mathrm{Mg}$ index was in the range of 3.24-5.39 for the aboveground parts and 2.88-5.83 for roots. The PDSs decreased the value of the index in the aboveground parts of plants, which was also confirmed in earlier studies [25]. Matraszek et al. [43] found that soil contamination with Ni significantly affected the values of $\mathrm{K} /(\mathrm{Ca}+\mathrm{Mg})$ and $\mathrm{Ca} / \mathrm{Mg}$ indices in the shoots and roots of spring wheat and that this effect was variable, depending on the applied dose and the analyzed part of the plant.

PDSs can modify the content of heavy metals in plants, and this effect varies and depends on the type of the analyzed component, the dose, and the type of applied compounds, as well as on the analyzed part of the plant $[25,27,28]$. In the conducted experiment, the PDSs usually increased the content of the analyzed heavy metals in the roots of broad bean plants. Rusin et al. [25] demonstrated an increase in the content of $\mathrm{Cu}$ and $\mathrm{Mn}$ in the roots of broad bean plants growing in soil contaminated with EO and DF; however, they did not find a similar relationship for the remaining heavy metals. In the conducted experiment, EO increased the $\mathrm{Zn}$ and $\mathrm{Cu}$ content in the aboveground parts of plants by $16.52 \mathrm{mg} \mathrm{kg}^{-1}$ and $2.54 \mathrm{mg} \mathrm{kg}^{-1}$. This phenomenon was also confirmed in our earlier studies conducted 3 years after contamination [27], where EO increased the content of the analyzed heavy metals in the broad bean leaves by approximately $15 \mathrm{mg} \mathrm{kg}^{-1}$ and $17 \mathrm{mg} \mathrm{kg}^{-1}$. In the abovementioned experiment [27], a significant increase in the $\mathrm{Pb}$ content in the leaves of plants was caused by the presence of PDSs in the soil; however, as indicated by the results of the present study, after two more years, this tendency was observed only in soil treated with $\mathrm{DF}$. Elevated $\mathrm{Pb}$ content in plants growing in soil contaminated with PDSs may result from its elevated content in the contaminated soil, which was reported by Ujowundu et al. [9]. The same study also showed elevated $\mathrm{Cd}$ and Fe content in soil contaminated with DF, which suggested the possibility of their increased concentration in plants. Rusin et al. [44] also confirmed increased Cd content in winter wheat. However, Gospodarek and Nadgórska-Socha [28] did not find any significant effect of PDSs on the content of Cd in the shoots of broad bean plants, a phenomenon that was also reflected in the present experiment. The authors also demonstrated that soil contaminated with $\mathrm{P}$ and $\mathrm{EO}$ at the dose of $3 \mathrm{~g} \mathrm{~kg}^{-1}$ decreased the Fe content in the leaves of broad bean plants to approximately $70 \mathrm{mg} \mathrm{kg}^{-1}$ and $35 \mathrm{mg} \mathrm{kg}^{-1}$, respectively. Moreover, in the present experiment, PDSs decreased the Fe content in the aboveground parts of broad bean plants in the range of $86.5-228.3 \mathrm{mg} \mathrm{kg}^{-1}$. The Fe content in leguminous plants ranges from 75 to $400 \mathrm{mg} \mathrm{kg}^{-1}$ [45]. The values obtained in the present study for the aboveground parts were in this range; thus, no clear deficiency of this element was observed. Reduced Fe content in plant tissues exposed to PDSs may be due to the antagonistic effect of other elements. Excessive amounts of metals such as $\mathrm{Mn}, \mathrm{Ni}$, and Co restrict the absorption and transport of Fe in plants. This antagonism also occurs in a reverse direction, i.e., excessive Fe content can inhibit the transport of other metals. A clear inhibition of $\mathrm{Fe}$ and $\mathrm{Mn}$ transport from roots to the aboveground parts of the plant was observed in the conducted experiment under the impact of PDSs. The obtained results confirmed the hypothesis that considerable variation occurs in heavy metal accumulation by the individual plant species in the presence of PDSs in soil. Presently, there are no data on the effects of PDSs on the content of Sr, $\mathrm{Ba}, \mathrm{As}$, and $\mathrm{Al}$ in plants. In the present study, although the PDSs generally increased the content of the analyzed heavy metals in the roots of plants, they sometimes also decreased the heavy metal content in the aboveground parts ( $\mathrm{Sr}$ content decreased by approximately $10 \mathrm{mg} \mathrm{kg}^{-1}$ in the EO and DF treatments). 
Changes in nutrient and heavy metal content may deteriorate the quality of the host plant for phytophagous insects and subsequently affect further links in the trophic chain. Thus, the increase in the content of heavy metals may cause the loss of utility value of plants.

Scarce data are available on the subsequent effect of enhanced bioremediation on the content of heavy metals in plants growing in soil contaminated with PDSs. Bioremediation can decrease the content of some metals to the levels obtained in the control treatment, as observed for $\mathrm{Pb}$ in our earlier study [27], but it may also increase the content of other metals $(\mathrm{Cd}, \mathrm{Ni}, \mathrm{Cu})$. In the present experiment, the biopreparation usually decreased the content of most of the analyzed heavy metals in the aboveground parts and roots of broad bean plants when it was applied to the soil contaminated with PDSs. Sometimes, however, it increased the content of some heavy metals, for example, an increase in the content of $\mathrm{Zn}$ by nearly $30 \mathrm{mg} \mathrm{kg}^{-1}$ in the DF treatment or a significant increase in $\mathrm{Cu}$ and $\mathrm{Ba}$ content in the P treatment. It should, however, be emphasized that a significant increase in $\mathrm{Zn}$ content in the aboveground parts of the plant was also observed after the application of ZB-01 to the control soil. A possible reason for this result may be the reduced soil $\mathrm{pH}$ (from 6.12 to 5.10 [pH in $\mathrm{KCl}$ ) after the application of the preparation [44]. The low $\mathrm{pH}$ level favors the absorption of the majority of heavy metals, which was also reflected in the experimental results obtained for $\mathrm{Cd}, \mathrm{Pb}, \mathrm{Ni}$, and $\mathrm{Cu}$ in the control soil. In the soils contaminated with PDSs, the application of the biopreparation increased soil $\mathrm{pH}$ by up to 0.5 units, which may partially explain the reduced content of the majority of heavy metals under the influence of the biopreparation.

In the available literature, limited information is present on the effect of soil contamination with PDSs, indirectly through the host plant, on feeding by herbivores. The studies performed to date highlight two major aspects of the adverse effects of PDSs on phytophages. The first aspect is associated with the worsening usability of the host plant. PDSs often cause weakened growth and development of plants, and they also modify the content of macro- and microelements, which can result in the worsened quality of food for herbivores (reduced content of N, P, protein, and chlorophyll) $[25,27,46,47]$; therefore, it can modify the process of their colonization of host plants. The second aspect is associated with the transportation of harmful substances from the soil through plants to phytophages, as PDSs contain heavy metals, polycyclic aromatic hydrocarbons (PAHs) and other chemical admixtures, which are toxic to living organisms. Rusin et al. [25] demonstrated that PDSs adversely affect the developmental parameters in Aphis fabae Scop. aphid, resulting in reduced fecundity, shortened lifespan, lengthened pre-reproduction period, and a decreased innate rate of population growth. The authors emphasized that this could be associated with the synergistic influence of the impairment of the host plant trophic value and the transfer of toxic substances from the soil through plants to the aphids.

Gospodarek [48] demonstrated that the contamination of soil by a mixture of $\mathrm{Zn}$ and $\mathrm{Ni}$, and by the mixture of these metals with $\mathrm{Pb}, \mathrm{Cu}$, or $\mathrm{Cd}$ significantly limited the feeding by Sitona spp. In the present experiment, the PDSs sometimes contributed to the increase in the content of the abovementioned heavy metals in the aboveground parts of plants (EO increased the content of $\mathrm{Zn}$ and $\mathrm{Cu}$, while DF increased the content of $\mathrm{Pb}$ ); this could partly explain their adverse effect on the feeding by imago of Sitona spp. A previous study [49] showed that even after 3 years of soil contamination with $\mathrm{Ni}, \mathrm{Cd}, \mathrm{Zn}$, $\mathrm{Cu}$, or $\mathrm{Pb}$, there was still no expected increase in the attractiveness of broad bean plants to Sitona spp. Multiple regressions in the present study revealed significant effects of only $\mathrm{Ca}, \mathrm{Mn}$, and $\mathrm{Fe}$ on this parameter. However, it should be noted that there could be a synergistic effect resulting from general changes in the composition of the host plant due to soil contamination with PDSs. This aspect needs further investigation.

A very interesting finding in the present experiment was that the PDSs did not adversely affect the feeding of Sitona larvae that were directly exposed to the contaminations. This may indicate the high resistance of Sitona larvae to soil contamination by PDSs; however, there is no information in the available literature to confirm this hypothesis.

There is scarce information on the effect of enhanced bioremediation on invertebrates, and the results pertain chiefly to soil organisms [50]. The studies, however, indicate that bioremediation can 
eliminate the adverse effects of PDSs [19,51]. A similar effect of the impact of ZB-01 biopreparation on PDS-contaminated soil was noted in the present study.

Summarizing, the obtained results indicate that PDSs, even after 5 years, negatively affect the feeding of phytophages, which can be inferred in terms of potential negative effects on further links of the food chain, i.e., for predators, parasitoids, and even human consumers.

\section{Conclusions}

- Five years after soil contamination by EO and DF, their negative impact on the growth of broad bean plants was still noted; this confirms the high persistence of the used contaminants in the soil environment and indicates the susceptibility of the plants to soil-derived contamination.

- The PDSs modified the content of nutrients in plant organs. They decreased the content of Ca and $\mathrm{Mg}$ in the aboveground parts of broad bean plants; however, a reverse relationship was noted for the roots of the analyzed plants. Furthermore, soil contamination with EO and DF increased the content of $\mathrm{K}$ and $\mathrm{P}$ in the aboveground parts of plants and $\mathrm{S}$ content in their roots.

- All the applied PDSs generally increased the content of heavy metals in the roots of plants; however, some of them also decreased the content of some metals, e.g., $\mathrm{Pb}, \mathrm{Zn}, \mathrm{Cu}, \mathrm{Mn}, \mathrm{Sr}$, and $\mathrm{Ba}$, in aboveground parts.

- The PDSs applied in the experiment negatively affected the feeding of adult Sitona spp., thereby causing a reduction in the percentage of plants damaged by beetles and a decrease in the surface of consumed areas on leaves; however, in the majority of cases, PDSs had no significant effect on the reduction in the size of leaf blade and on the feeding of larvae of the studied insect. Positive ( $\mathrm{Ca}, \mathrm{Mn}, \mathrm{Mg}, \mathrm{Ba}, \mathrm{P})$ and negative $(\mathrm{Fe}, \mathrm{Mn}, \mathrm{K})$ relationships were observed between the contents of some elements and the feeding of imago and larvae of Sitona spp. Changes in the chemical composition of plants might deteriorate the nutritional quality of the host plant, thus decreasing their attractiveness for the imago of Sitona.

- The ZB-01 biopreparation applied in the experiment had a generally positive effect on the morphological features of plants, and its effect on the content of nutrients and heavy metals was variable, depending on the type of contaminant, the analyzed metals or nutrients, and the involved part of the plant. It often eliminated the differences in the content of various nutrients and heavy metals between the broad bean plants growing in the contaminated soil and the control soil. The biopreparation usually also inhibited the adverse effect of PDSs on feeding by imago of Sitona spp. beetles.

Author Contributions: Conceptualization, J.G. and A.N.-S.; Investigation, J.G., M.R. and A.N.-S.; Methodology, J.G. and A.N.-S.; Writing-original draft, J.G., M.R. and A.N.-S. All authors have read and agreed to the published version of the manuscript.

Funding: Scientific publication financed from the funds for science in 2009-2013 as a research project (N N305 151537) and by the Ministry of Science and Higher Education of the Republic of Poland.

Conflicts of Interest: The authors declare no conflict of interest. The funders had no role in the design of the study; in the collection, analyses, or interpretation of data; in the writing of the manuscript, or in the decision to publish the results.

\section{References}

1. Liang, Y.; Nostrand, J.D.; Deng, Y.; He, Z.; Wu, L.; Zhang, X.; Li, G.; Zhou, J. Functional gene diversity of soil microbial communities from five oil-contaminated fields in China. Mic. Popul. Commun. Ecol. 2011, 5, 403-413.

2. Mendrycka, M.; Mucha, K.; Stawarz, S. Bioremediacja związków ropopochodnych oraz szlaki ich biodegradacji. Post. Mikrobiol. 2013, 52, 397-408.

3. Jørgensen, K.S.; Puustinen, J.; Suortti, A.M. Bioremediation of petroleum hydrocarbon-contaminated soil by composting in biopiles. Environ. Pollut. 2000, 107, 245-254. [CrossRef] 
4. Das, N.; Chandran, P. Microbial degradation of petroleum hydrocarbon contaminants, an overview. Biotechnol. Res. Int. 2011, 1, 1-13. [CrossRef] [PubMed]

5. Jahangeer, A.; Kumar, V. An overview on microbial degradation of petroleum hydrocarbon contaminants. IJETR 2013, 1, 34-37.

6. Samanta, S.K.; Singh, O.V.; Jain, R.K. Polycyclic aromatic hydrocarbons: Environmental pollution and bioremediation. Trends Biotechnol. 2002, 20, 243-248. [CrossRef]

7. Gospodarek, J. Effect of oil derivative spill on epigeal mezofauna. Proc. ECOpole 2008, 2, 309-314.

8. Ndimele, P.E. A review on the phytoremediation of petroleum hydrocarbon. Pak. J. Biol. Sci. 2010, 13, 715-722. [CrossRef]

9. Ujowundu, C.O.; Kalu, F.N.; Nwaoguipke, R.N.; Kalu, O.I.; Ihejirika, C.E.; Nwosunjoku, E.C.; Okechukwu, R.I. Biochemical and physical characterization of diesel petroleum contaminated soil in southeastern Nigeria. Res. J. Chem. Sci. 2011, 1, 57-62.

10. Carmona, M.; Zamarro, M.T.; Blazquea, B.; Durante-Rodriques, G.; Juarez, J.F.; Valderrama, J.A.; Barragan, M.J.L.; Garcia, J.L.; Diaz, E. Anareobic catabolism of aromatic compounds: A genetic and genomic view. Microbiol. Mol Biol. Rev. 2009, 73, 71-133. [CrossRef]

11. Chen, K.F.; Kao, C.H.M.; Chen, C.H.W.; Surampalli, R.Y.; Lee, M.S. Control of petroleum-hydrocarbon contaminated groundwater by intrinsic and enhanced bioremediation. J. Environ. Sci. 2010, 22, 846-871. [CrossRef]

12. Jain, P.K.; Gupta, V.K.; Gaur, R.K.; Lowry, M.; Jaroli, D.P.; Chauhan, U.K. Bioremediation of petroleum oil contaminated soil and water. Res. J. Environ. Toxicol. 2011, 5, 1-26.

13. Meintanis, C.; Chalkou, K.I.; Kormas, K.A.; Karagolini, A.D. Biodegradation of crude oil by thermophilic bacteria isolated from a volcano island. Biodegradation 2006, 17, 105-111. [CrossRef] [PubMed]

14. Haritash, A.K.; Kaushik, C.P. Biodegradation aspects of Polycyclic Aromatic Hydrocarbons (PAHs), A review. J. Hazard Mater. 2009, 169, 1-15. [CrossRef]

15. Milić, J.S.; Beškoski, V.P.; Ilić, M.V.; Ali, S.A.M.; Gojgić-Cvijović, G.Đ.; Vrvić, M.M. Bioremediation of soil heavily contaminated with crude oil and its products: Composition of the microbial consortium. J. Serb. Chem. Soc. 2009, 74, 455-460. [CrossRef]

16. Das, K.; Mukherjee, A.K. Crude petroleum-oil biodegradationefficiency of Bacillus subtilis and Pseudomonas aeruginosa strains isolated from petroleum-oil contaminated soil from North-East India. Bioresour. Technol. 2007, 98, 1339-1345. [CrossRef]

17. Margesin, R.; Hammerle, M.; Tschenrko, D. Microbial activity and community composition during bioremediation diesel-oil-contaminated soil: Effects of hydrocarbon concentration, fertilizers and incubation time. Microb. Ecol. 2007, 53, 259-269. [CrossRef]

18. Tsai, T.T.; Kao, C.M.; Yeh, T.Y.; Liang, S.H.; Chien, H.Y. Remediation of fuel oil-contaminated soils by a three-stage treatment system. Environ. Eng. Sci. 2009, 26, 1779-1785. [CrossRef]

19. Gospodarek, J.; Petryszak, P.; Kołoczek, H. The effect of the bioremediation of soil contaminated with petroleum derivatives on the occurrence of epigeic and edaphic fauna. Biorem. J. 2016, 20, 38-53. [CrossRef]

20. Petryszak, P.; Kołoczek, H.; Kaszycki, P. Biological treatment of wastewaters generated by furniture industry. Part 1. Laboratory-scale process for biodegradation of recalcitrant xenobiotics. Ecol. Chem. Eng. A 2008, 15, 1129-1141.

21. Liste, H.; Felgentreu, D. Crop growth, culturable bacteria and degradation of petrol hydrocarbons (PHCs) in a long-term contaminated field soil. Appl. Soil Ecol. 2006, 31, 43-52. [CrossRef]

22. Njoku, K.L.; Akinola, M.O.; Busari, T.O. Effect of time of application of spent oil on the growth and performance of maize (Zea mays). Afr. J. Environ. Sci. Technol. 2012, 6, 67-71. [CrossRef]

23. Lopes, A.; Piedade, M.T.F. Experimental study on the survival of the water hyacinth (Eichhornia crassipes (Mart.) Solms-Pontederiaceae) under different oil doses and times of exposure. Environ. Sci. Pollut. Res. 2014, 21, 13503-13511. [CrossRef]

24. Rusin, M.; Gospodarek, J.; Nadgorska-Socha, A. The effect of petroleum-derived substances on chemical composition of winter wheat. Ecol. Chem. Eng. A 2016, 23, 199-210.

25. Rusin, M.; Gospodarek, J.; Nadgórska-Socha, A.; Barczyk, G. Effect of petroleum-derived substances on life history traits of black bean aphid (Aphis fabae Scop.) and on the growth and chemical composition of broad bean. Ecotoxicology 2017, 26, 308-319. [CrossRef] [PubMed] 
26. Rusin, M.; Gospodarek, J.; Nadgórska-Socha, A.; Barczyk, G.; Boligłowa, E.; Dabioch, M. Effect of petroleum-derived substances on life history traits of bird cherry-oat aphid (Rhopalosiphum padi L.) and on the growth and chemical composition of winter wheat. Environ. Sci. Pollut. Res. 2018, 25, 27000-27012. [CrossRef]

27. Rusin, M.; Gospodarek, J.; Nadgórska-Socha, A. The effect of petroleum-derived substances on the growth and chemical composition of Vicia faba L. Pol. J. Environ. Stud. 2015, 24, 2157-2166. [CrossRef]

28. Gospodarek, J.; Nadgorska-Socha, A. Chemical composition of broad beans (Vicia faba L.) and development parameters of black bean aphid (Aphis fabae Scop.) under conditions of soil contamination with oil derivatives. J. Elem. 2016, 21, 1359-1376. [CrossRef]

29. Wyszkowski, M.; Ziółkowska, A. Effect of compost, bentonite and calcium oxide on content of some macroelements in plants from soil contaminated by petrol and diesel oil. J. Elem. 2009, 14, 405-418. [CrossRef]

30. Malallah, G.; Afzal, M.; Gulshan, S.; Abraham, D.; Kurian, M.; Dhami, M.S.I. Vicia faba as a bioindicator of oil pollution. Environ. Pollut. 1996, 92, 213-217. [CrossRef]

31. Grant, W.F.; Lee, H.G.; Logan, D.M.; Salamone, M.F. The use of Tradescantia and Vicia faba bioassays for the in situ detection of mutagens in an aquatic environment. Mutat. Res. 1992, 270, 53-64. [CrossRef]

32. Kanaya, N.; Gill, B.S.; Grover, I.S.; Murin, A.; Osiecka, R.; Sandhu, S.S.; Anderson, H.C. Vicia faba chromosomal aberation assay. Mutat. Res. 1994, 310, 231-247. [CrossRef]

33. Moraru, P.I.; Rusu, T.; Bogdan, I.; Pop, A.I.; Chetan, F. Variations of soil physical characteristics under the influence of crop rotation and soil tillage systems. SGEM 2016, 2, 461-468.

34. Kęsik, T.; Konopiński, M.; Błażewicz-Woźniak, M. Effect of pre-winter soil tillage and cover crop mulches on water retention, compaction and differential porosity of soil after winter time. Acta Agroph. 2006, 7, 915-926.

35. Lin, A.; Zhang, X.; Zhu, Y.G.; Zhao, F.J. Arsenate induced toxicity: Effects on antioxidative enzymes and DNA damage in Vicia faba. Environ. Toxicol. Chem. 2008, 27, 413-419. [CrossRef]

36. Nadgórska-Socha, A.; Ptasiński, B.; Kita, A. Heavy metal bioaccumulation and antioxidative responses in Cardaminopsis arenosa and Plantago lanceolata leaves from metalliferous and non-metalliferous sites: A field study. Ecotoxicology 2013, 22, 1422-1434. [CrossRef]

37. Pezeshki, S.R.; Hester, M.W.; Lin, Q.; Nyman, J.A. The effects of oil spill and clean-up on dominant US Gulf coast marsh macrophytes. Environ. Pollut. 2000, 108, 129-139. [CrossRef]

38. Wake, H. Oil refineries: A review of their ecological impacts on aquatic environment. Estuarine Coastal Shelf Sci. 2005, 62, 131-140. [CrossRef]

39. Szarlip, P.; Stelmach, W.; Jaromin-Gleń, K.; Bieganowski, A.; Brzezińska, M.; Trembaczowski, A.; Hałas, S.; Łagód, G. Comparison of the dynamics of natural biodegradation of petrol and diesel oil in soil. Desalin. Water Treat. 2014, 52, 3690-3697. [CrossRef]

40. Borowik, A.; Wyszkowska, J. Remediation of soil contaminated with diesel oil. J. Elem. 2018, 23, 767-788.

41. Wyszkowski, M.; Wyszkowska, J. Effect of enzymatic activity of diesel oil contaminated soil on the chemical composition of oat (Avena sativa L.) and maize (Zea mays L.). Plant Soil Environ. 2005, 51, 360-367. [CrossRef]

42. Morgan, J.B.; Connolly, E.L. Plant-soil interactions: Nutrient uptake. Nat. Educ. Know. 2013, 4, 2.

43. Matraszek, R.; Hawrylak-Nowak, B.; Chwil, S.; Chwil, M. Macronutrient composition of nickel-treated wheat under different sulfur concentrations in the nutrient solution. Environ. Sci. Pollut. Res. Int. 2015, 23, 1-13. [CrossRef]

44. Rusin, M.; Gospodarek, J.; Barczyk, G.; Nadgórska-Socha, A. Antioxidant responses of Triticum aestivum plants to petroleum-derived substances. Ecotoxicology 2018, 27, 1352-1367. [CrossRef] [PubMed]

45. Kabata-Pendias, A.; Pendias, H. Biogeochemia Pierwiastkow Śladowych; Wydawnictwo Naukowe PWN: Warszawa, Poland, 1993; p. 364.

46. Nadgórska-Socha, A.; Gospodarek, J.; Jaworska, M.; Ciepał, R. Content of assimilation pigments, phosphorus and protein in broad bean Vicia faba L. ssp. maior grown in heavy metals contaminated soils. Ecol. Chem. Eng. 2005, 12, 421-426.

47. Odjegba, V.J.; Atebe, J.O. The effect of used engine oil on carbohydrate, mineral content and nitrate reductase activity of leafy vegetable (Amaranthus hybridus L.). J. Appl. Sci. Environ. Manag. 2007,11, 191-196. [CrossRef]

48. Gospodarek, J. Atrakcyjność bobu dla oprzędzików (Sitona spp.) w warunkach zanieczyszczenia gleby mieszaninami metali ciężkich. Prog. Plant Prot. 2012, 52, 791-795. 
49. Gospodarek, J. Residual effect of soil contamination with heavy metals on Sitona spp. beetles feeding on broad bean (Vicia faba L.). Ecol. Chem. Eng. A 2011, 18, 1565-1570.

50. Rusin, M.; Gospodarek, J. The occurrence of springtails (Collembola) andspiders (Araneae) as an effectiveness indicator of bioremediation of soil contaminated by petroleum- derived substances. Int. J. Environ. Res. 2016, 10, 449-458.

51. Gospodarek, J.; Rusin, M. Residual effect of soil pollution with oil derivatives on the occurrence of Acarina. Proc. ECOpole 2015, 9, 71-77.

(C) 2020 by the authors. Licensee MDPI, Basel, Switzerland. This article is an open access article distributed under the terms and conditions of the Creative Commons Attribution (CC BY) license (http://creativecommons.org/licenses/by/4.0/). 